Board of Governors of the Federal Reserve System

International Finance Discussion Papers

Number 579

March 1997

\title{
AN ECONOMETRIC MODEL OF CAPITAL FLIGHT FROM DEVELOPING COUNTRIES
}

Lisa M. Schineller

NOTE: International Finance Discussion Papers are preliminary materials circulated to stimulate discussion and critical comment. References in publications to International Finance Discussion Papers (other than an acknowledgment that the writer has had access to unpublished material) should be cleared with the author or authors. Recent IFDPs are available on the Web at www.bog.frb.fed.us. 


\title{
AN ECONOMETRIC MODEL OF \\ CAPITAL FLIGHT FROM DEVELOPING COUNTRIES
}

Lisa M. Schineller

\begin{abstract}
This paper analyzes capital flight from a group of seventeen developing nations over the period 1978 to 1993 . The paper briefly discusses several empirical definitions of capital flight and presents estimates of capital flight for the sample based on some of these measures. In general, the data reveal periodic episodes of dramatic flight through the late 1980s, at which point many nations began to experience strong capital inflows. Anecdotal evidence for the nations in our sample underpins our hypothesis that capital flight is driven by a heightened, pervasive risk which reflects the degree of domestic macroeconomic imbalance which is domestically undiversifiable. Our econometric model of the determinants of capital flight extends previous empirical studies of flight by expanding both the cross section of nations and time horizon of analysis. Given the panel data set, we consider a country specific error component to account for the possibility of unobserved country heterogeneity and employ fixedeffects and random-effects estimation. We instrument for potentially endogenous explanatory variables and in doing so consider a fixed-effects system. The results, based on several different measures of flight, highlight the importance of modelling flight with a country specific error component. While other proxies of the risk associated with macroeconomic imbalance are not significant, the central government surplus is negatively, statistically significantly related to flight. This highlights the motivation of investors to move capital both to escape future taxation directly and indirectly via monetization of deficits. Therefore, even when taking into account other measures of risk, the higher taxation risk, both directly and indirectly through expectations of future inflation, dominates the regressions.
\end{abstract}

Keywords: capital flight, macroeconomic risk, panel data

${ }^{*}$ Economist in the International Finance Division of the Federal Reserve Board. I would like to thank Hali Edison, Bill Helkie, David Howard and Catherine Mann for comments, Gian Maria Milesi-Ferretti, Carmen Reinhart, and Mark Stone for discussions while a Visiting Scholar at the Research Department, International Monetary Fund, and Sam Kim and Luzmaria Monasi for Research Assistance. The views expressed in this paper are the author's and should not be interpreted as reflecting those of the Board of Governors of the Federal Reserve System or other members of its staff. 


\section{$1 \quad$ Introduction}

This paper analyzes capital flight among developing countries, where capital flight refers to international capital movements which respond to heightened domestic economic and political uncertainty. While this paper focuses on the experiences of developing countries, the essence of capital flight lies not in the level of economic development, but in the degree of economic, social, and political fracture. Indeed, capital flight has characterized both developed and developing nations throughout this century.

During the late 1970s and 1980s capital flight plagued many developing nations; the concurrent LDC Debt Crisis prompted both theoretical and empirical analyses of flight. However, widespread interest in the topic abated as the immediacy of the crisis subsided, foreign lending dissipated, and countries embarked upon stabilization and structural adjustment programs. Towards the end of the 1980s many developing countries began to enjoy renewed capital inflows of a substantial magnitude.

Euphoria surrounding "emerging markets" developed in the early 1990s as a new breed of traders, lacking a potentially more sober perspective that bankers from the early 1980s might offer, discovered relatively high-return (and high-risk) investment opportunities in many of the previously flight-afflicted developing countries. The research literature then addressed the sustainability of these capital inflows; these analyses raised the possibility that the capital inflows in fact were not driven primarily by domestic reform, but a conspicuous lacuna of attractive foreign (U.S.) investment opportunities, and that much of the investment in emerging markets was domestic investors reversing capital flight of the 1980s and hence limited in scope.

The political and economic events which occurred in Mexico throughout 1994, culminating with the devaluation of the peso in December, highlighted the fragility of these renewed capital inflows to emerging markets. In response to the Mexican crisis, international 
investors, investors of any nationality and residence with access to global capital markets, reduced their investment in Mexico and other emerging markets. Capital flight recurred.

Despite the negative connotation associated with the term capital flight, its impact on an economy is ambiguous. Indeed, only when its potentially detrimental effects are borne out during a crisis do economists, policy makers, politicians, bankers, and investors focus on its possible adverse effects on an economy, or potential for systemic contagion. The possible disruptive effects on domestic investment, the foreign exchange market and public finances which stem from flight become more severe and a greater possibility when one considers the magnitude of flight for some developing countries. ${ }^{1}$ Flight on the order of 5 to 10 percent of GNP represents a substantial outflow of resources from the domestic economy.

Defining capital flight empirically and quantifying its magnitude proves to be elusive. The paper first highlights several of the empirical measures we employ. It presents data on the magnitude of capital flight for a sample of seventeen developing countries from 1978 to 1993. We briefly comment on how flight has evolved for the sample as a whole, as well as within Latin America and Asia. In addition, we present the conclusions we have drawn upon comparing cross-country anecdotal evidence with the observed patterns of flight in both countries and regions to motivate the econometric model.

For policy to be effective in stemming or reversing flight, it is important to quantify the determinants of flight. This paper extends previous econometric analyses of the determinants of capital flight among developing nations. This econometric study specifically attempts to examine the relationship between capital flight and the degree of macroeconomic mismanagement, postulated to generate a domestically undiversifiable risk that can significantly reduce the returns on domestic investment. Our results are based on more data than were previously available and a more sophisticated modelling of the error term. The econometric results indicate a significant 
inverse relationship between the central government surplus and capital flight, as well as the importance of modelling country-specific heterogeneity. This result highlights the motivation of domestic residents to move capital both to escape future taxation directly and indirectly via monetization of deficits. Therefore, even when taking into account other measures of risk, the higher taxation risk, both directly and indirectly through expectations of future inflation, dominates the regressions.

\section{Empirical measures of capital flight}

Capital flight statistics are not readily available, instead they must be constructed. Since there is no universal definition of capital flight, the literature offers several different approaches for devising flight estimates. ${ }^{2}$ The estimates of capital flight this paper presents are based on the residual approach, which is premised on circumventing the use of "unreliable" Balance of Payments (BOP) capital account data, and calculates flight indirectly. This approach posits that the recorded increase in gross foreign debt provides a better measure of net foreign loans, foreign loans less amortization, than do BOP data. The residual approach yields generally broad measures of flight, and we present capital flight data based on three somewhat different residual approach definitions (discussed in greater detail in an Appendix).

The World Bank (1985) defines capital flight as the change in a nation's foreign assets. It is premised on trying to identify both the sources and uses of international funds by a nation; source funds consist of the increase in recorded gross external debt and net foreign direct investment, which can in turn be used to finance the current account and/or to increase official reserves. In essence, it equates capital flight with all non-official capital outflows.

Dooley (1988) presents another variation of the residual approach which attempts to distinguish between so called normal and flight capital flows. According to Dooley, flight stems 
from the desire to avoid domestic taxation. As such, flight need not be a current transaction, but merely reflect a change in the motive for holding a previously acquired foreign asset as the domestic investment climate changes. He defines flight as that stock of foreign assets whose returns have not been reported as investment income (in BOP statistics). Should all capital outflows and investment income on them be reported, there would be no capital flight under Dooley's approach. For comparative purposes, our "Dooley" estimates are the change in Dooleyderived stock figures.

We present a third "residual" capital flight measure which in essence is a combination of the World Bank and Dooley methodologies; we call it the Modified-World Bank approach. A detailed comparison of the World Bank and Dooley measures reveals that besides the stock versus flow measurement, the key conceptual and empirical distinction between them lies in Dooley's attempt to differentiate all capital outflows from flight flows, where flight is driven by tax avoidance. The Modified-World Bank measure offers an easy way to calculate Dooley flows - capital flight flows broadly defined to encompasses both short and long term non-official capital outflows (the World Bank measure) less any capital outflow that corresponds with a desire to avoid domestic taxation.

All empirical measures of capital flight are subject to criticism, and, while employing it, we acknowledge that the residual approach is not above critique. In using this measure, the magnitude of flight varies with the accuracy and comprehensiveness of debt coverage. For example, the debt component suffers from valuation effects as the U.S. dollar fluctuates. In addition, this measure, as do all the other measures in the literature, fails to capture flight associated with trade mis-invoicing. Since it does not distinguish between normal and supernormal non-official portfolio movements, the World Bank measure overestimates flight by the 
amount of normal portfolio movements stemming from differences in tastes, technology and endowments, and portfolio movements associated with trade transactions. In capitalizing certain BOP items, the Dooley approach is subject to measurement error through both the choice of some world interest rate and the reliability of the BOP data. Thus, it is prudent to focus on the relative magnitudes of these flight estimates and how they change over time, and not specific flight estimates.

\section{$3 \quad$ Cross country comparisons}

We have calculated estimates of capital flight for all seventeen nations in our sample for each of the three measures just discussed. Chart 1 and Tables 1 and 2 provide estimates of flight based on the three measures for the entire sample and a regional break-down; in Table 3 we present estimates of capital flight for each of these nations based on the Modified-World Bank Approach. The three alternative measures of flight discussed in the previous section are conceptually quite close, and should be highly correlated. Indeed, the correlation coefficients between the World Bank and Modified-World Bank, and World Bank and Dooley Flow measures are both 0.71, while the correlation coefficient between the Modified-World Bank and Dooley Flow measures is somewhat higher at 0.92 (as would be expected). As the estimates of capital flight in Table 3 reveal, the seventeen developing nations in our sample have experienced different degrees of capital flight, and flight reversal, between 1978 and 1993. Some nations have suffered from dramatic levels of capital flight during the 1980s, but have more recently enjoyed flight reversal. Others nations, while less afflicted by flight, have received substantial capital inflows more recently as well.

In order to draw more general conclusions on capital flight, we consider the overall pattern of flight for those nations in our sample. As implied by Table 1 and Chart 1, on a GNPweighted basis, capital flight from our sample of countries averaged about 1.6 percent of GNP 
through 1982 and accelerated during 1985 and 1987 averaging 2.5 percent of GNP. Only after 1989 on average did flight decelerate sharply; between 1990 and 1993 capital inflows averaged 2.5 percent of GNP. Our estimates are consistent with general discussions on the magnitude of flight from developing countries.

When we dis-aggregate our sample into Latin American and Asian countries, the overall pattern of flight and flight reversal is surprisingly not too dis-similar. In line with general perceptions, flight was more pronounced from Latin America during the late 1970s and early 1980s. Between 1978-1982, flight from Latin America averaged 1.7 percent of GNP, compared with 1.4 percent of GNP for Asia. When we consider the period 1978-1984, the different regional experiences become more dramatic: while flight from Asia averaged 0.9 percent of GNP, flight from Latin America averaged twice that, at 2.0 percent of GNP. Both groups of countries experienced re-newed flight in the mid-1980s (although we do not quantify it, some of the resurgence in flight from Asia may be attributed to the impact of U.S. dollar depreciation on the valuation of external debt). While flight from Latin America averaged 2.8 percent of GNP between 1985-1987, flight from Asia was a bit more moderate at 2 percent of GNP. However, both regions enjoyed substantial capital inflows from 1990-1993. Inflows to these Latin American economies averaged 2.6 percent of GNP, while those to Asia were slightly lower at 2.4 percent of GNP.

Our comparison of anecdotal evidence on country-by-country macroeconomic policy and capital flight patterns (based on the three alternative flight measures) confirms commonly held perceptions of the determinants of capital flight. Pronounced flight occurred when a nation experienced severe macroeconomic imbalances, including a combination of substantial fiscal deficits, overvalued exchange rates, high and/or volatile inflation, and ambitious financial sector liberalization. Furthermore, political instability and domestic unrest, which was sometimes, but 
not necessarily related to the economic situation, prompted flight. We posit that flight occurred as the risk associated with local investment stemming from mismanaged domestic policy became relatively high, and the risk premia associated with expected domestic returns failed to adequately reflect the potential for losses. Anecdotal evidence also seems to indicate that if policy inconsistencies and/or political unrest co-existed with an open capital account, more flight probably occurred than had the capital account been closed (effectively). We draw this conclusion after considering the both the magnitude of flight from and relative open capital accounts of Mexico, Argentina, Venezuela, Indonesia and Malaysia as opposed to the lower flight and tighter controls in Brazil, Colombia, India and Korea.

The estimates reveal a marked reversal of flight episodes at the end of the 1980s. Capital inflow has in general been accompanied by the implementation of macroeconomic stabilization and structural adjustment programs (and perhaps aided by the decline in returns in industrialized nations). Flight reversed when nations embarked on deficit reduction, exchange rate re-alignment, and trade liberalization and privatization programs. It seems that only when such reform was not short-lived and/or perceived as credible (obviously not easily quantifiable) did significant capital flight reversal occur.

Our analysis of individual country commentaries provides a basis for the determinants of capital flight we present in the fifth section. We conclude that domestic policy underpins the motive to engage in capital flight, and flight reversal. Similar macroeconomic imbalances seem to have characterized both those Latin American and Asian nations who underwent pronounced capital flight episodes. Not surprisingly, successful, sustained and credible correction of these imbalances, at least in part, attracted a return of capital to these very nations by the early 1990s.

\section{$4 \quad$ Econometric studies}

Econometric studies of the determinants of capital flight from developing nations is not 
extensive. Three primary analyses, each with a slightly different focus, are Cuddington (1986), Varman (1989), and Dooley (1988). Cuddington (1986) takes a narrow, conventional rate of return approach to the determinants of flight. ${ }^{3}$ Varman (1989) uses econometric modelling to quantify the magnitude of capital flight, not its determinants where flight is the fraction of gross capital outflows motivated by the discriminatory treatment of domestic capital, political upheaval, and uncertainty. ${ }^{4}$ In modelling the determinants of capital flight, Dooley (1988) incorporates the notion that domestic and foreign investors face asymmetric risk when investing in a developing economy and this risk asymmetry determines the magnitude of capital flight. ${ }^{5}$ Dooley's model considers inflation, financial repression, and a risk premium on external debt as explanatory variables. $^{6}$

This econometric model of capital flight uses Dooley (1988) as its starting point. First, Cuddington's focus on short term capital outflows is too narrow; "hot money" flight can be achieved through longer maturity, but very liquid financial instruments. In addition, it is unlikely that the conventionally measured rates of return Cuddington employs fully reflect the differences in the returns and risks between domestic and foreign investment. While fully acknowledging all the caveats that accompany an explicit measure of flight, we are uncomfortable with Varman's econometric flight measurement methodology. Dooley offers the most encompassing attitude towards the risk that determines flight, employs some panel-data estimation techniques -- our preferred modeling strategy, and his model outperforms the other two models. The determinants of flight we posit (discussed in the next section) do differ from Dooley's since he focused on asymmetric risk; our notion of risk associated with domestic policy mismanagement may, but need not be, asymmetric.

This econometric study differs from those just described in extending the time frame of the sample, including nations not traditionally thought to experience flight, considering alternative 
models of the error term, and implementing instrumental variable estimation techniques. With the appropriate estimation techniques to control for the effects of missing or unobserved variables, a larger time series-cross section data set should generate more reliable econometric results. While Dooley (1988) utilizes a panel data set and employs panel data estimation techniques, that study did not consider and compare a random-error variance components model with the fixedeffects model. In addition, the variables which serve as instruments in his estimation are themselves potentially endogenous.

\section{$5 \quad$ The empirical model}

\subsection{The dependent variable : capital flight}

The dependent variable in our panel data model is capital flight as a proportion of GNP, $\mathrm{CF}_{\mathrm{it}} / \mathrm{GNP}_{\mathrm{it}}$. As noted there is no one agreed upon measure of capital flight in the literature. Given our strong preference for a broad measure of flight and desire to compare econometric results across alternative measures, we estimate the model using each of the three "residual" capital flight measurements discussed in Section 2.

\subsection{The determinants of flight}

Our approach towards modelling the determinants of capital flight goes beyond relying on conventionally measured rates of return to capture the relationship between a pervasive risk generated by domestic policy and capital flight. Our intent is to capture the need for macroeconomic adjustment. It should be noted that in our previous econometric work we also considered other proxies of the need for macroeconomic adjustment, such as the level and volatility of inflation, without success. In addition, no internally consistent, comprehensive index of political stability or political risk was available for our sample period. ${ }^{7}$ We have tried to capture political instability with a variable that summarizes turnover in the executive branch of 
the government in previous econometric analyses. ${ }^{8}$ However, due to the conceptual difficulties associated with this measure and the fact our measures failed to be statistically significant, we did not include them in this analysis.

A conventional indicator of the risk between domestic and foreign assets is the differential in domestic and foreign interest rates adjusted for expected depreciation of the exchange rate; indeed both Cuddington (1986) and Dooley (1988) consider this variable. We measure this risk premium with the difference between short term commercial bank deposit rates in country $i$ and the three month U.S. dollar-denominated LIBOR adjusted for actual depreciation of country i's official exchange rate in U.S. dollar terms. Since many developing country domestic financial markets are in the earlier stages of development, the use of these deposit rates seems appropriate. We expect a negative relationship between this interest rate differential and the dependent variable, capital flight.

If domestic and foreign assets are not perfect substitutes, as expected, the risk premium will not be zero, and this differential should capture both default and country risk. However, in many developing countries, such asset returns are not fully market determined; financial repression characterizes their financial markets. Under these circumstances, this differential will not fully reflect the risks associated with domestic investment. Thus, we include other measures of risk in this econometric analysis.

A large fiscal deficit potentially signals fiscal mismanagement and/or instability. The need for future fiscal adjustment, be it through formal taxation or inflationary financing, clearly reflects the risks associated with the domestic policy environment. Given that we could not obtain data on the consolidated public sector's fiscal position, we include the central government surplus as a share of GNP as an explanatory variable. We anticipate a negative relationship between the government surplus and flight. 
The premium for foreign exchange in the black market serves as another indication of the risk associated with domestic investment. When official exchange rates are not market determined and there are restrictions on capital flows, the black market premium often reflects the market's perception of domestic policy sustainability. Suppose domestic credit expands; a fixed official exchange rate remains constant while a freely floating black market exchange rate depreciates. The black market premium reflects policy inconsistency and portends eventual official devaluation; the implied losses on domestic assets prompts agents to engage in flight. We define the black market premium as the ratio of the black market exchange rate to the official exchange rate and expect a positive relationship with flight. ${ }^{9}$

The credibility and perceived sustainability of government policy underpin the motive to engage in capital flight. Agenor and Taylor (1993) propose a methodology to derive a credibility index for exchange rate policy. It entails decomposing the black market premium into its "fundamental" and "non-fundamental" components, and using the latter as a measure of credibility. The non-fundamental component consists of the estimated residuals from individual country ARDL regressions of the black market premium on its determinants. ${ }^{10}$ We estimate the ARDL model using monthly data; the annual coefficient of variation of these residuals serves as the exchange rate credibility index in our capital flight model. As an alternative to the black market premium, we include this variable as a regressor in our model to capture the risks associated with exchange rate policy. We expect a positive relationship between the nonfundamental component, representing incredible policy, and flight.

In general, the economies of nations experiencing capital flight are in a state of crisis. Many of these nations implement austerity programs to stabilize the economy. By imposing external discipline on a nation, an IMF austerity program may render reform more credible and help restore confidence in the domestic economy, since it is often accompanied by renewed 
foreign financing and agreements on debt rescheduling. We anticipate that the imposition of an IMF stabilization program would diminish the risk associated with domestic investment in such an economy. We include a dummy variable which assumes a value of zero or one to indicate whether or not a given nation was subject to an IMF agreement in a given year in our model of flight, and expect a negative relationship with flight.

Restrictions on international capital mobility most probably will affect the feasibility of undertaking flight, and the relative magnitude of flight across nations. In their analysis of the effectiveness of capital controls, Grilli and Milesi-Ferretti (1994) consider different types of controls, not merely controls on new capital account outflows. The overall effectiveness, or degree of tightness, of a capital control regime is captured by a more comprehensive examination of controls, i.e. including different measures of capital controls. We explicitly control for different capital and current account restrictions across nations. Using the IMF Annual Report on Exchange Arrangements and Exchange Restrictions, we constructed dummy variables which assume a value of one when a restriction was in place (otherwise zero). The dummies correspond to restrictions on payments for current and capital transactions, cost-related import restrictions, the need to surrender or repatriate export proceeds, and whether there are separate exchange rate(s) for some or all capital transactions and/or some or all invisibles.

The secondary market price for a country's bank debt should provide a broad indication of the market's assessment of a country's credit-worthiness, and hence reflects perceptions of domestic policy environment. Stone (1991) finds that secondary market prices do indeed reflect subjective views of country risk not captured by macroeconomic variables. ${ }^{11}$ While we cannot purge these secondary debt prices of widespread domestic macroeconomic observables given data constraints, we only include the component of secondary market prices that is orthogonal to world interest rates and the IMF's international commodity price index for developing countries as a 
regressor. As lower international interest rates immediately reduce a given debt-service burden; higher commodity prices should directly improve the external debt repayment capabilities of commodity exporters. However, the probable rise in secondary debt prices associated with such improved repayment prospects does not stem from domestic policy reform. Thus, we include the annual coefficient of variation of the residuals from individual country regressions based on monthly data as another determinant of capital flight in our econometric model, and anticipate a negative relationship with capital flight.

\section{$6 \quad$ Estimation methodology}

The flight expression we estimate is

$$
\begin{aligned}
& y_{i t}=x_{i t}{ }^{`} \beta+\varepsilon_{i t}, \quad i=i, \ldots, N, \\
& t=1, \ldots, T .
\end{aligned}
$$

The sample consists of seventeen heavily indebted developing nations who have experienced different degrees of flight between 1978 and 1993. When working with panel data it is very unlikely that

$$
\varepsilon_{\mathrm{it}} \sim \text { iid } \mathrm{N}\left(0, \sigma_{\varepsilon}^{2}\right)
$$

Countries have different histories and political and financial institutions which may affect the attitude of a country's agents toward engaging in flight. ${ }^{12}$ To control for possible country specific effects which are invariant through time, we model unobserved persistent country heterogeneity with a one factor error components model:

$$
\varepsilon_{\text {it }}=\eta_{\mathrm{i}}+v_{\mathrm{it}}
$$

where

$$
v_{\mathrm{it}} \sim \operatorname{iid} \mathrm{N}\left(0, \sigma_{\mathrm{v}}^{2}\right)
$$

Should (3) characterize the data, OLS estimation of (1) yields inefficient parameter estimates 
since the covariance matrix associated with (3) is not scalar. ${ }^{13}$ GLS estimation techniques must be employed to obtain asymptotically efficient parameter estimates. To determine whether or not a homogeneous error structure is appropriate, we employ the Breusch-Pagan specification test designed to detect the presence of $\eta_{\mathrm{i}}{ }^{14}$

Panel data models assume that $\eta_{\mathrm{i}}$ are either fixed or drawn from random distributions; the fixed-effects assumption is a special case of the random-effects assumption. Random-effects models posit

$$
\eta_{\mathrm{i}} \sim \operatorname{iid} \mathrm{N}\left(0, \sigma_{\eta}^{2}\right) \text {. }
$$

We employ the Wu-Hausman specification test to determine whether the appropriate error components are fixed or drawn from a random distribution.

The GLS estimate of $\beta$ in (1) is unbiased and consistent only as long as $\mathrm{E}\left(\varepsilon_{\mathrm{it}} \mid \mathrm{x}_{\mathrm{it}}\right)=0$. We propose that two of our explanatory variables violate this expression. While a higher black market premium may prompt flight serving as a measure of the risk of a devaluation, the black market exchange rate is at the same time the relevant exchange rate for many international transactions, including asset imports or capital outflows, especially when legal capital flows are restricted. In addition, we posit simultaneity between the government surplus and flight. While large fiscal deficits signal eventual macroeconomic adjustment and prompt flight, under a source based system of taxation, flight may diminish government revenues.

While we assume that $\mathrm{E}\left(\eta_{\mathrm{i}} \mid \mathrm{x}_{\mathrm{it}}\right)=0$, we acknowledge the likelihood that $\mathrm{E}\left(\mathrm{v}_{\mathrm{it}} \mid \mathrm{x}_{\mathrm{it}}\right) \neq 0$ due to the endogeneity of the black market premium and the government surplus. As suggested by Griliches and Hausman (1986), we control for such simultaneity bias with instrumental variable estimation in which the fitted values from reduced form estimation of the black market premium and government surplus serve as instruments. ${ }^{15}$ With panel data, lagged values of the black market premium and deficit are inappropriate instruments under the assumption of correlated 
individual effects.

\section{$7 \quad$ Empirical Results}

While we estimate the capital flight model, equation (1), using the three broad capital flight measures discussed in the second section: the World Bank Measure, the Modified-World Bank Measure and the Dooley Flow Measure, we only report estimation results based on the Modified-World Bank Approach since they did not differ from the results based on the other two measures in a substantive manner. Tables 4 through 7 present these results when instrumental variable estimation entails using the fitted values from reduced form $O L S$ estimation. The Breusch-Pagan specification test always rejects the null hypothesis of an identically distributed error term against a country specific variance component model. Thus, it is appropriate to estimate the model with a variance components error structure. The results from the $\mathrm{Wu}$ Hausman specification test, however, are not as definitive. ${ }^{16}$ While estimating the model with a country-specific error-component is clearly appropriate, there is no firm conclusion on whether a fixed or random-effects estimation technique is preferred.

As expected, the central government surplus is negatively, statistically significantly related to flight. The model consistently suggests that large government deficits might prompt capital flight. This highlights the motivation of investors to move capital both to escape future taxation directly and indirectly via monetization of deficits. Despite estimating the model with alternative sub-sets of the postulated determinants, the other proxies of the risk associated with macroeconomic imbalance are not significant. It appears that the higher taxation risk, both directly and indirectly through expectations of future inflation, dominates the regressions.

The interest rate differential, adjusted for actual depreciation of the official exchange rate, does not prove to be a reliable measure of the relative risk associated with domestic investment, as it is always statistically insignificant. Furthermore, while it generally does exhibit the expected 
negative relationship with flight during the entire period 1978-1993, this is not the case when we estimate the model from the late 1980s through 1993. In contrast to the results from similar econometric work based on data through 1988 (with a slightly different cross section of nations), data for this sample through 1988 indicate a strong negative relationship between this variable and flight. However, this is not the case when estimating the model beyond 1988, or for example, when we include the secondary market price as a regressor (which restricts both the time frame and cross section of the sample) as seen in Tables 6 and 7; then, while still insignificant, this differential is positive. ${ }^{17}$

According to our results, in so far as the black market exchange rate reflects a nation's macroeconomic policy stance, it fails to underpin flight. While almost never statistically significant, in most instances the black market premium is negatively related to flight. The negative relationship is not as robust as in our previous econometric work (where it also was statistically significant). This result would imply that a higher black market premium does not reflect greater risk to domestic investment because of imminent devaluation, and prompt flight. For the premium to reflect such a risk, there must be both a (semi) fixed official rate and capital restrictions. Only then will any instability that might generate flight be reflected in a higher black market premium. With an open capital account and floating official exchange rate, flight can respond to such increased risk, but at the same time the black market premium need not capture this risk. Anecdotal evidence for several countries indicates that this is a possible explanation for our results. ${ }^{18}$ The credibility index for exchange rate policy ${ }^{19}$ fails to perform much better as a proxy for the credibility and perceived sustainability of exchange rate policy. While of the anticipated positive sign in general, it is statistically insignificant.

The IMF adjustment program variable usually is (statistically) insignificantly, negatively correlated with flight; however, it does perform better when the sample is restricted the late 1980s 
and beyond (Tables 6 and 7). This provides weak evidence that an IMF program lends credibility to a stabilization program and stems flight. However, an IMF presence entails different implications across countries. It may aggravate domestic unrest and exacerbate flight. Alternatively, it may capture the mere fact that the economy requires significant macroadjustment, which would imply a positive relationship with flight.

The capital control variable is systematically insignificant; on average its coefficient is negative (as anticipated) in less than half the cases. The results are based on a control measure in which we sum the dummy variables corresponding to restrictions on payments for capital transactions, the need to surrender or repatriate export proceeds, and the existence of separate exchange rate(s) for some or all capital transactions and/or some or all invisibles. In previous econometric results based on a more simplistic capital control measure (restrictions on capital account outflows), this coefficient was consistently (insignificantly) positive; we attributed this in part to the fact that this control measure imperfectly reflected the intensity of capital account restrictions. This motivated our use of a more comprehensive capital control measure, albeit without definitive success.

When included, the secondary price of bank-debt ${ }^{20}$ does not enter statistically significantly in the model. The coefficient is negative reflecting the possibility that higher secondary prices signal improved credit-worthiness, which might dampen flight. However, there is no definitive evidence of this hypothesis.

We also considered an alternative error-term specification. Instead of using instruments (for the black market premium and government surplus) based on reduced form $O L S$ estimation, we modelled the instruments with an error components structure. Should the black market premium and government surplus be subject to country specific heterogeneity, the OLS based fitted values would not be the most efficient instruments. Indeed after performing the Breusch- 
Pagan specification test for the black market premium and government surplus, we rejected a homogeneous error term. Thus, it would be more appropriate to postulate and estimate a simultaneous-equations system for flight, the black market premium and the surplus, where all three endogenous variables possess an error structure of the general form in equation (3). When performing fixed-effects on the simultaneous system of three equations, we only estimate the structural equation for the flight equation. ${ }^{21}$

There is no dramatic improvement in these results, which appear in Tables 8 and 9 for the Modified-World Bank measure of capital flight, compared with those based on the OLS instruments. $^{22}$ On average the government surplus continues to be negatively, statistically significantly related with flight. However, in general, the other variables continue to be statistically insignificant, and not always of the anticipated sign.

In light of the overall shift from capital flight to capital inflows that occurred around the end of the 1980s according to our estimates of capital flight, and as depicted in Chart 1, we have broken our sample into two periods to determine whether or not the data support a structural break in our model. We estimate our model (instrumenting for the black market premium or employing the black market credibility index, but with the without the secondary market price variable) from 1978 to 1988 , and then from 1989 to 1993 . When doing so, the explanatory power of the government surplus declines, but consistently performs better in the latter period. Furthermore, we reject the hypothesis of no structural break in the data, at the 99 percent confidence level. Thus, the data for our group of developing nations support the existence of a different model to explain the evolution of capital flight through the late 1980s and capital inflows which occurred thereafter. It appears that fiscal deficit reduction attracted capital inflows, while such deficits did not underpin flight in the earlier period; the weaker results for the earlier period are consistent with the difficulties we encountered in previous econometric work in 
determining what prompt capital flight.

We also test for different behavior of the model across the Latin American and Asian nations in our sample. When we estimate the model for the eleven Latin American nations, the government surplus remains statistically significant; however, for the six Asian nations, none of the explanatory variables are significant. Nonetheless, in testing for significantly different behavior of the model between these two regions, we do not reject the hypothesis that the same model underpins both regions. While there appears to be a different dynamic over time for this econometric modelling of capital flight and flight reversal, this is not present between the Latin American and Asian regions, once we have controlled for country specific effects.

\section{$8 \quad$ Conclusion}

This paper presents estimates of capital flight for seventeen developing nations since the late 1970s through the early 1990s based on the World Bank, Modified-World Bank and Dooley methodologies described in Section 2. These data indicate instances of dramatic flight until the late 1980s, at which point many nations experienced strong capital inflows. The capital flight estimates have been used in concert with anecdotal evidence on cross-country economic imbalances and political events to motivate the proposal that capital flight responds to a domestically undiversifiable risk, which is determined by the stance of domestic policy. Investors hedge against this risk with foreign asset accumulation.

For those countries in our sample, substantial fiscal and current account deficits, overvalued exchange rates, high and/or volatile inflation, and ambitious financial sector liberalization most commonly generate flight. Similarly, macroeconomic adjustment and structural reform seem to entice capital inflow. The individual country commentaries and existing 
econometric studies on flight provide the basis for the econometric model of flight we estimate.

Our econometric model uses a panel data set, which includes a longer time horizon and nations not traditionally thought to have experienced flight, as well as the alternative measures of capital flight. We consider alternative models of the error term and instrumental variable estimation techniques. The results indicate that either a fixed-effects or random-effects error components structure should be assumed; the Breusch-Pagan test rejects a homogeneous error structure. However, the Wu-Hausman test does not provide definitive support for the use of random-effects over fixed-effects. We also present results from a fixed-effects simultaneousequations system; future research might consider a random-effects system.

Our results confirm the importance of the government's budget surplus as a potential determinant of capital flight. Despite estimating the model with alternative sub-sets of the postulated determinants, the other proxies of the risk associated with macroeconomic imbalance are not significant. It appears that taxation risk, both directly and indirectly through expectations of future inflation, dominates the regressions. The other proxies may not adequately capture macroeconomic risk; this highlights the need to continue considering alternative measures of this risk, all of which are likely affected by measurement error.

The data point to a structural break in the model beginning in the late 1980s. The data indicate that the set of independent variables does not equally explain both the pattern of flight which characterized the sample through 1988, and the pattern of capital inflows, or flight reversal, which occurred thereafter. However, there is no structural break for a Latin American and Asian regional breakdown of the cross-section.

In comparing these results with the previous literature, recall that we employ somewhat different measures of flight, consider a more thorough analysis of the possible error structure 
implied by the data and a more extensive sample. We tried, albeit without complete success, to include other broad measures of the risk associated with domestic investment than those considered by Dooley (1988). Dooley (1988) was able to obtain a statistically significant relationship between flight and the differential in interest rates adjusted for actual depreciation also of the expected sign, while we were not. Cuddington (1986), however, also failed to achieve the more definitive results that Dooley (1988) did for both inflation and conventionally measured rates of return variables.

Future extensions of the model with alternative risk measures should clearly consider an error components model. While the data for the regressors we employ may be too crude to explain the pattern of flight, they do highlight the importance of country-effects. Although our data set is more comprehensive than that used in other studies, the results may suffer from small sample bias. In addition, given that, in general, the macroeconomic risk that underpins the motive for flight, is also exacerbated by the realization of flight, it proves difficult to completely avoid the econometric problem of simultaneity between any set of explanatory variables reflecting this broad concept of risk and the dependent variable. While we instrument for the black market premium and central government surplus, the other determinants (interest rate differential, IMF presence, capital controls) probably are not independent of flight; while we cannot instrument for all our explanatory variables, future research might consider instrumenting for alternative combinations. Furthermore, as more time series data become available, one should continue to consider whether there are fundamentally different determinants of capital flight and capital inflows, as our work seems to imply, given its potentially important policy implications. 


\section{Notes}

1. The perception that flight drains domestic resources that could, should and would have been allocated towards domestic investment and production is open for question. Should flight occur directly at the expense of efficient and productive net domestic investment, growth will be affected. When capital inflows no longer finance capital flight, flight must be financed with a fall in net imports or a reduction in official international reserves, which may have real effects on the economy. Flight that exacerbates shortages of and intensifies competition for foreign exchange can result in excess volatility of exchange rates or the collapse, or major devaluation, in a fixed exchange rate regime.

In addition, some institutional features of developing countries imply that massive capital outflows have a potentially detrimental effect on the economy. Given the dependence upon source based taxation and seigniorage of many developing countries, flight could adversely affect public finances as the domestic tax base erodes. Any adverse impact on public finances entails distributional consequences, and efficiency consequences if taxation is distortionary. The distributional consequences for domestic agents are potentially exacerbated by the asymmetry between ownership of private foreign assets and liabilities in developing countries. After the debt crisis it became quite apparent that while private foreign assets are strictly private, private foreign liabilities are effectively public. To the extent that capital flight is financed by foreign borrowing, this asymmetry socializes private risk, which is potentially inefficient and inequitable.

2. The balance of payments approach, as its name suggests, uses capital account to measure capital flows. While the errors and omissions component of balance of payments statistics do not exclusively represent unreported capital flows, the literature generally accepts their being primarily unreported capital flows. Employing this methodology, Cuddington (1986) defines flight as short-term speculative outflows by the non-bank private sector, or "hot money". He quantifies flight as short term capital outflows and errors and omissions, which he equates with unreported short-term capital movements.

A second approach relies on data on cross-border bank deposits. The IMF and BIS publish such data on a country-by-country basis. Since they exclude all non-bank-deposit investment vehicles, these statistics generate a relatively narrow measure of capital flight. However, since they are a direct measure of reported foreign asset accumulation, they may be subject to less measurement error.

2. Besides the already mentioned use of World Bank flight estimates as the basis for calculating Dooley flows, Claessens and Naude (1993) further modify both the World Bank and Dooley methodologies (which we do not implement). When using the change in external debt, they make some adjustment for the effect of cross currency exchange rate fluctuations and debt forgiveness. More important conceptually, they modify how "source" funds are defined in both approaches. First they define external debt inclusive of short-term and IMF debt, but exclusive of private, non-guaranteed debt, so capital inflows are restricted to net official inflows or increases in net external indebtedness of the public sector. Second, they augment net foreign direct investment with net purchases of corporate equities, which are considered part of flight in many other contexts.

As a result of these in essence conceptual adjustments, the Claessens and Naude flight estimates are lower than if one used total (official and non-official) inflows or the change in total external debt. The authors define external indebtedness in this manner to derive net private 
external claims. They argue that private external indebtedness represents an actual liability of the private sector (expected to be serviced and repaid by the private sector) and do not deem it appropriate to consider the simultaneous acquisition of a private foreign asset and foreign liability capital flight. This argument has been disputed.

First, this is the argument raised by banks in the 1980s in reducing new lending at that time. Second, Diaz Alejandro (1984) highlights the asymmetry between ownership of private foreign assets and liabilities in developing countries. During the debt crisis it became quite apparent that while private foreign assets are strictly private, private foreign liabilities are not, indeed they are effectively public. To the extent that capital flight is financed by foreign borrowing, this asymmetry socializes private risk, which is potentially inefficient and inequitable. Dooley and Kletzer (1994) raise this point as well in their discussion on the subsidization of foreign lending. Third, a theoretical literature based on risk asymmetry developed to specifically address the phenomenon of capital flow simultaneity and would consider such flows flight (Khan and Ul Haque (1987). Indeed, Dooley (1988) constructed his measurement in response to this literature by acknowledging a risk asymmetry between resident and non-resident investment in a developing country.

3. Cuddington (1986) posits a demand equation for foreign assets based upon a stockadjustment portfolio model where the assets include a domestic inflation hedge, and a domestic and foreign interest bearing asset. He estimates the model separately using yearly data from 1974 to 1982 for eight countries: Argentina, Brazil, Chile, Korea, Mexico, Peru, Uruguay, and Venezuela using OLS and IV estimation.

4. After controlling for capital outflows associated with trade and normal portfolio transactions, Varman (1989) regresses total capital outflows on dummy variables which assume values of one during those years in which she deems political and economic disarray to have prompted capital flight. She measures total capital out flows as the change in total external claims and calculates the total external claims according to Dooley's methodology of combining external debt statistics with capitalized balance of payments flows. She employs OLS and 2SLS to analyze flight from India from 1971 to 1985 and the Philippines from 1976 to 1985 . Note that Varman \& Schneider (1989) tests whether the particular dummy event structure for flight imposed in Varman (1989) is consistent with the data. In doing so Varman \& Schneider (1989) employ flexible least squares. The structure imposed on India is confirmed, while that for the Philippines is not.

5. The concept of risk asymmetry underpins theoretical work attempting to explain the simultaneity of capital inflows and outflows many developing nations experienced in the late 1970 s and early 1980s. This work proposes that domestic investors face greater risk of loss than do foreign investors on their investment in a developing economy.

6. Dooley (1988) performs country specific fixed-effects IV estimation for five developing countries between 1976 and 1983. Dooley instruments for inflation and financial repression using the fiscal deficit/GNP and debt/GNP, and interest payments/GNP, respectively. The nations in the sample included Argentina, Brazil, Mexico, the Philippines, and Venezuela.

7. Jodice and Taylor (1983) constructed one such index, but its coverage ended in 1982. 
8. Based on Bienen and van de Walle (1991), we constructed a variable which indicated when a change in executive leadership occurred. To incorporate when the change in executive leadership also entailed a switch in the governing party, we adjusted this variable after consulting various issues of Banks' Political Handbook of the World. These measures of political instability, however, do not capture instability unless it is associated with a change in leadership; this is not necessarily representative of political risk. If the political system entails a regularly timetable for elections, higher government turnover may not be a sound indicator of instability. Given this and the fact that these variables were very insignificant in all the estimations, we turned to other political risk measures.

9. Because the black markets are often thin, the data on black market exchange rates may be noisy. In addition, the black market premium does not merely reflect devaluation or political instability. The premium is affected by the costs associated with going through the black market, including the risk detection. It also reflects the decision by exporters as to how much to surrender to the black market, which is a function of the premium itself. In addition, the importance of and the activity in the black market does vary from country to country and from time period to time period. While the premium does not only represent political risk, and may not be the best representative of political risk, nevertheless, the market rate, and its premium, are in many instances relevant to the mechanics of engaging in flight as well as the decision to undertake flight.

10. Following Agenor and Taylor (1993), we posit the following determinants of the black market premium: the change in money supply (M1) and industrial output, domestic and foreign inflation, and seasonal dummies.

11. In his econometric analysis, Stone (1991) employs panel-data estimation techniques. He first purges Business International country risk ratings of certain macro-economic observables (such as debt/GDP, reserves/imports, real GDP, log CPI, industrial country output, arrears/total debt). The residuals from these BI regressions represent the unobservable "subjective" inputs to country risk judgements; these are then included as an explanatory variable with the same macro observables in the model of secondary market prices. These residuals are statistically significant: secondary market prices capture important aspects/subjective views regarding country risk, not captured by macroeconomic variables.

12. Hajivassiliou (1989) notes that unobserved country specific heterogeneity has been overlooked in most work on developing country debt, but should not be. He motivates the importance of accounting for such heterogeneity along two lines; we extend their intuition to the flight scenario. First, nations differ in terms of colonial history and current political, religious and financial institutions. These differing characteristics may affect the attitude of a country's agents towards engaging in capital flight. This unobserved heterogeneity introduces serial correlation within the error term structure for each nation. Second, previous flight crises may be good predictors of future flight crises. Such a learning process also introduces serial correlation in the data.

13. The variance-covariance matrices for the error term specification in equation (3) is $\Sigma_{\varepsilon}=\sigma_{v}^{2} \mathrm{I}_{\mathrm{NT}}+\sigma_{\eta}^{2}\left(\mathrm{I}_{\mathrm{NT}} \otimes \mathrm{i}_{\mathrm{T}} \dot{\mathrm{i}}_{\mathrm{T}}{ }^{\prime}\right)$

$\mathrm{I}_{\mathrm{NT}}$ denotes an NTxNT identity matrix, $\mathrm{i}_{\mathrm{T}}$ an Tx1 unit vector, and $\otimes$ the Kronecker product. 
14. The Breusch-Pagan specification test entails performing OLS on the model of interest and forming a test statistic using the residuals.

15. The instrumental variable estimation technique devised by Hausman and Taylor (1981) accounts for any correlation between $\eta_{i}$ and $x_{i t}$ under random-effects, which would lead to biased and inconsistent parameter estimates. We do assume that $E\left(\eta_{i} \mid x_{i t}\right)=0$ in our estimation, but perform conventional instrumental variable estimation to correct for simultaneity bias stemming from: $\mathrm{E}\left(\mathrm{v}_{\mathrm{it}} \mid \mathrm{x}_{\mathrm{it}}\right) \neq 0$.

Dornbusch et. al. (1983), Fishelson (1988) Kaufman and O’Connell (1990), Agenor (1990), and Phylaktis (1992) provide the basis for the determinants of the black market premium. In its most comprehensive form, the structural equation for the black market premium in this three equation system includes: the real official exchange rate, the differential in domestic and foreign interest rates adjusted for actual depreciation of the official exchange rate, change in the domestic money supply (M1), growth of GNP and the presence of capital controls (and capital flight).

Roubini and Sachs (1989a) and (1989b) provide the underlying framework for formalizing the structural equation for the government surplus. In its most general form, this structural equation includes the lagged domestic real deposit rate and U.S. Treasury Bill rate, lagged public external debt, inflation and growth of GNP (and capital flight).

16. The results from the $\mathrm{Wu}$-Hausman specification test do not provide a definitive preference for fixed or random-effects. When estimating the model based using the World Bank measure of capital flight, we accept the null hypothesis that random-effects is the most efficient estimation technique. However, when using the other two measures of flight, more often we reject this null hypothesis or cannot calculate the test-statistic (which is negative, presumably due to the implementation of instrumental variable estimation). The negative test statistic does offer some weak support for maintaining the null hypothesis of random-effects. Clearly, the data support the assumption of an heterogeneous error-structure, but do not provide definitive support for the assumption of fixed vs. random-effects.

We were unable to successfully perform goodness of fits to examine the robustness of the model. Both the Likelihood-ratio tests and F-tests for such hypotheses were negative. We attribute this to (i) possible small sample bias, (ii) possible measurement error and/or (iii) the use of instrumental variable estimation techniques as described. Hence we only report the value of the log-likelihood function.

In estimating the reduced form for the black market premium with OLS, the variables that were significant and of the expected sign include: capital controls, the change in the money supply, and GNP growth. Capital controls and expansive money supply tend to raise the premium; growth lowers the premium. While insignificant, the differential on interest rates and inflation are positively and negatively related to the premium, respectively; not what theory dictates. The IMF variable and lagged public external debt are significantly negative; the lagged U.S. LIBOR is significantly positive; the lagged domestic interest rate is insignificantly positive. The reduced form explains approximately $20 \%$ of the black market premium. When included, the secondary price is insignificantly negative and reduces the significance of some of the other explanatory variables $\left(\mathrm{R}^{2}\right.$ is $\left.10 \%\right)$.

Using OLS, the reduced form fitted values for the government surplus capture about $18 \%$ of the determinants of the surplus. As expected, GNP growth exhibits a significant positive relationship with the surplus, lagged U.S. LIBOR is significant and negative; lagged public 
external debt is negative, but insignificant. Inflation exhibits a significant positive correlation with the surplus, but growth in the money supply is significantly negative. The lagged domestic interest rate is negative, but insignificant. The IMF, capital control and interest differential variables are positive and insignificant. When included, the secondary price is significantly negative, not intuitive $\left(\mathrm{R}^{2}\right.$ is $\left.30 \%\right)$. When included, the non-fundamental component of the black market exchange rate is negative, but insignificant $\left(\mathrm{R}^{2}\right.$ is $16 \%$ to $\left.25 \%\right)$.

17. In our previous analyses, we attributed the positive coefficient to the fact that since we considered actual, not expected, depreciation, the results were (and remain) vulnerable to the "peso problem" in which agents may anticipate a depreciation that does not materialize ex-post. Agents might have engaged in flight based on an expected differential, which is not captured by our data. Alternatively, as a risk premium, this differential may indeed be detecting a higher degree of risk in the domestic economy, but the magnitude of the risk premium not compensate investors for domestic risk, agents would instead engage in flight generating a positive relationship between flight and this risk premium. Of course these caveats still apply to the results presented here.

18. Argentina suffered from significant flight from the late 1970s through 1982; however, since its capital account was relatively open, the black market premium was close to zero. Similarly, in the late 1980s, the Philippines experienced flight as the Marcos regime was in turmoil. However, since the peso was floating, there was not a large black market premium. The World Bank Development Report (1989) notes that Mexico and Venezuela permitted freer capital movements than Sweden when they experienced flight; rising political risk in Venezuela prompted massive flight, but the black market premium was negligible in light of the open capital account. Similarly, Malaysia suffered large flight, but had almost no black market premium as the rupiah floated and the capital account was open. While Brazil restricted capital flows and did not experience nearly as much flight as its Latin American neighbors initially, it did exhibit a relatively large premium.

19. The credibility index of exchange rate policy is based on the annual coefficient of variation (over monthly data) of the non-fundamental component of the black market exchange rate, or the residuals, from the following estimation. We estimated the first equation of an ARDL system of the black market premium on current and lagged values of the change in the domestic money supply, domestic inflation rate, U.S. inflation rate, depreciation of the official exchange rate, and seasonal monthly dummies. In general, we used between 2 to 3 lags after performing both an F-test and LR-test to determine the optimal number of lags for each nation. The explanatory power of the model averaged 63\% (median 65\%), ranging from $8 \%$ (Brazil) to $93 \%$ (Ecuador).

20. The secondary market price regressor we employ is the annual coefficient of variation of the residuals from monthly OLS estimation of the secondary market price on the U.S. 3-month LIBOR and the IMF's international commodity price index for developing countries. In almost all the individual regressions, the U.S. interest rate was negative and statistically significant, while the commodity price index was positive (which we would expect for an exporting nation), but insignificant. The explanatory power of the model averaged 33\% (median 24\%), ranging from 0\% (Bolivia and Brazil) to 82\% (Mexico). 
21. Within this system, there is most likely some correlation between $\eta_{\mathrm{i}}$ across equations. Some of the country specific institutional or historical features that are likely to affect flight, will also affect the black market premium and government surplus as well. As noted by Hsiao (1986), such correlation implies that the statistical properties of the single equation panel data estimator do not in general carry over to a simultaneous-equations system. Since single-equation estimators do not exploit the cross-equation correlations between $\eta_{i}$, they would not yield consistent and asymptotically efficient estimates for a simultaneous-equations system. However, if the unobserved country-specific effects have a fixed-effects structure, the single-equation methodology does yield consistent and asymptotically efficient estimates in the simultaneousequations system. Fixed-effects estimation techniques involve estimating the model in terms of individual observations as deviations from the appropriate time or country means; the estimation "sweeps out" the individual effects $\eta_{i}$ and one can estimate each equation separately.

22. All in all, with fixed-effects estimation, the results still remain mixed. The reduced form model now explains about $32 \%$ of the variation of the black market premium, as opposed to about $20 \%$ using OLS. The explanatory variables exhibit mostly the same correlation with the revised premium estimate as they did with the OLS estimates. Differences include a significant positive coefficient for the interest rate differential (not expected); expected positive (still insignificant) inflation coefficient; positive and significant lagged U.S. LIBOR; insignificant lagged public external debt and growth coefficient. When included, the secondary price is still insignificantly negative (with an $\mathrm{R}^{2}$ of $11 \%$ ).

With fixed-effects, the reduced form government surplus equation now captures about $44 \%$ of the variation in the surplus, an increase from 18\%. Most of the key explanatory variables increase in their significance; the lagged U.S. LIBOR is still negative, but now significant but the lagged public external debt is still significant, but unexpectedly positive. The capital controls is now negative and significant, while the interest rate differential and IMF variables are now insignificant, but still positive. When included, the secondary price is still significantly negative, not intuitive ( $\mathrm{R}^{2}$ of $55 \%$ ). When included, the non-fundamental component of the black market exchange rate is negative, but insignificant $\left(\mathrm{R}^{2}\right.$ of 42 to $\left.47 \%\right)$. 


\section{Appendix 1: Definitions of the Residual Approach to Capital Flight Measurement}

According to the World Bank (1985) approach, flight is calculated as the difference between the increase in gross external debt and net foreign direct investment, and the current account balance and increase in official reserves. Flight consists of identified private capital outflows (both short and long-term), net errors and omissions and the discrepancy between BOP debt flows and the change in the stock of external World Bank debt.

Dooley (1988) constructs the stock of flight capital for a nation from external debt statistics and capitalized BOP data. Capital flight is the difference between the stock of total external claims and estimates of interest earning claims on foreigners, or reported claims. Total claims on foreigners are calculated first by capitalizing certain BOP data debit items and errors and omissions, excluding foreign direct investment outflows. However, because Dooley believes there is a discrepancy between BOP and debt data (where the former usually underestimate debt accumulation), the discrepancy between capitalized BOP debt estimates and World Bank debt figures is added to the total claims figure initially calculated; he considers this discrepancy to represent unreported claims on non-residents. To arrive at estimates of the total reported interest earning claims, Dooley capitalizes the value of investment income credits from the BOP data. Yearly capital flight stock estimates are the difference between the total claims and total reported claims on foreigners.

While conceptually analogous to the Dooley flight flows, the Modified-World Bank approach combines both the World Bank and Dooley methods of actually calculating capital flight. Both empirical approaches are consistent in their BOP accounting methodology (demarcation of BOP credit and debit entries) and the preference for external debt data over BOP data. They differ because Dooley considers the stock of reported foreign assets (calculated by capitalizing BOP current account "other investment receipts" credit items at the current world interest rate) not to be flight. The Modified-World Bank measure offers an easy way to calculate Dooley flows - capital flight flows broadly defined to encompasses both short and long term non-official capital outflows (the World Bank measure) less any capital outflow that corresponds with a desire to avoid domestic taxation. We adjust our World Bank estimates in the spirit of Dooley following the lead of Claessens and Naude (1993). ${ }^{2}$ Starting with our World Bank flow estimates, we subtract from them the change in the stock of reported foreign assets implied by the BOP data (calculated as described above) to generate our Modified-World Bank estimates. 


\section{Appendix 2: Data Sources}

Abbreviation for Data Sources:

BOP: Balance of Payments Statistics, IMF, computer tape.

IFS: International Financial Statistics, IMF, computer tapes and various issues.

WDT: World Debt Tables, World Bank, computer diskette.

WTA: World Tables, World Bank, computer diskette.

WCY: World Currency Yearbook, various issues.

IMF: IMF Annual Report, various issues.

FX: Annual Report on Exchange Arrangements and Exchange Restrictions, IMF, various issues.

Variables:

Flight: WDT, BOP, and IFS.

GNP: WDT.

Official Exchange Rates (average): IFS.

Interest rates: IFS and internal IMF data base.

Black market exchange rates: WCY.

CPI: IFS.

Money supply (M1): IFS.

Central government surplus: Internal IMF data base.

Public external debt: WDT.

IMF dummy variable: IMF.

Capital control dummy variable: Grilli and Milesi-Ferretti (1994) and FX.

Secondary Prices of Bank-debt : Stone (1990) and updated data. 


\section{References}

Agenor, Pierre-Richard and Mark P. Taylor (1993) "Analyzing Credibility in HighInflation Countries: A New Approach," The Economic Journal, 103, March, 329-336.

Agenor, Pierre-Richard (1990) "Stabilization Policies in Developing Countries with a Parallel Market for Foreign Exchange," IMF Staff Papers, Vol. 37, No.3, 560-592, September.

Bienen, Henry and van de Walle (1991) Of Time and Power: Leadership Duration in the Modern World. Stanford, CA: Stanford University Press.

Breusch, T.S. and A.R. Pagan (1980) "The Lagrange Multiplier Test and its Applications to Model Specification in Econometrics," Review of Economic Studies, XLVII, 239-253.

Buiter, Willem H. (1988) "Some Thoughts on the Role of Fiscal Policy in Stabilization and Structural Adjustment in Developing Countries," CEPR Discussion Paper no. 260.

Calvo, Guillermo A., Leonardo Leiderman, and Carmen Reinhart (1993) "The Capital Inflows Problem: Concepts and Issues," IMF Paper on Policy Analysis and Assessment no. 93/10.

Calvo, Guillermo A., Leonardo Leiderman, and Carmen Reinhart (1993) "Capital Inflows and Real Exchange Rate Appreciation in Latin America," IMF Staff Papers, Vol. 40, No. 1 (March), 108-150.

Calvo, Guillermo A., Leonardo Leiderman, and Carmen Reinhart (1992) "Capital Inflows to Latin America: the 1970s and the 1990s," IMF Working Paper no. 92/85.

Claessens, Stijn and David Naude (1993) "Recent Estimates of Capital Flight," World Bank Working Paper no. 1186.

Cuddington, J.T. (1986) "Capital Flight: Issues, Estimates and Explanations," Princeton Studies in International Finance no. 58.

Cumby, R.E. and R.M. Levich (1987) "On the Definition and Magnitude of Recent Capital Flight," NBER Working Paper no. 2275.

Deppler, Michael and Martin Williamson (1987) "Capital Flight: Concepts, Measurement, and Issues," Staff Study: Research Department of the International Monetary Fund. Washington DC: International Monetary Fund.

Diaz-Alejandro, Carlos (1984) "I Don’t Think We Are in Kansas Anymore," by Carlos Diaz-Alejandro, Brookings Papers on Economic Activity, 2, 335-403.

Dooley, Michael P., Eduardo Fernandez-Arias, and Kenneth M. Kletzer (1994) "Recent Private Capital Inflows to Developing Countries: Is the Debt Crisis History?," NBER Working Paper no. 4792. no. 4792. 
Dooley, Michael P. and Kenneth M. Kletzer (1994) "Capital Flight, External Debt and Domestic Policies," NBER Working Paper no. 4793.

Dooley, Michael P. (1988) "Capital Flight: A Response to Differences in Financial Risks," IMF Staff Papers, 422-436.

Dooley, Michael P. (1986) "Country Specific Risk Premiums, Capital Flight, and Net Investment Income Payments in Selected Developing Countries". IMF unpublished paper.

Dornbusch, Rudiger (1984) "External Debt, Budget Deficits and Disequilibrium Exchange Rates," NBER Working Paper no. 1336.

Dornbusch, Rudiger, et. al. (1983) "The Black Market for Dollars in Brazil," Quarterly Journal of Economics, 25-40.

Fishelson, Gideon (1988) "The Black Market for Foreign Exchange: An International Comparison," Economic Letters, 27, 67-71.

Greene, William (1990) Econometric Analysis. New York: MacMillan.

Griliches, Zvi and Jerry A. Hausman (1986) "Errors in Variables in Panel Data," Journal of Econometrics, 31, 93-118.

Grilli, Vittorio and Gian Maria Milesi-Ferretti (1994) "Structural Determinants and Economic Impact of Capital Controls," preliminary draft.

Hajivassiliou, Vassilis (1989) "Do Secondary Markets Believe in Life after Debt?," in Dealing with the Debt Crisis, eds., Ishrat Husain and Ishac Diwan. Washington DC: The World Bank.

Hausman, Jerry A. and William E. Taylor (1981) "Panel Data and Unobservable Individual Effects," Econometrica, Vol. 49, No. 6, 1377-1398.

Hsiao, Cheng (1986) Analysis of Panel Data. Cambridge: Cambridge University Press.

Jodice David A. and Charles Lewis Taylor (1983) World Handbook of Political and Social Indicators. New Haven, CT: Yale University Press.

Johnston, J. (1984) Econometric Methods. New York: McGraw Hill Book Company.

Judge, George G. et. al. (1985) The Theory and Practice of Econometrics. New York: John Wiley and Sons.

Kaufman, Daniel and Stephen A. O'Connell (1990) "The Macroeconomics of the Unofficial Foreign Exchange Market in Tanzania," mimeo, May.

Lessard, D.R. and J. Williamson (1987) Capital Flight and Third World Debt. Washington 
DC: Institute for International Economics.

Lim, Y.C. and Pang Eng (1991) Foreign Direct Investment and Industrialization in Malaysia, Singapore, Taiwan, and Thailand. Paris: OECD.

Phylaktis, Kate (1992) "The Black Market for Dollars in Chile," Journal of Development Economics, 37, 155-172.

Robinson, David et. al. (1991) Thailand: Adjusting to Success, Current Policy Issues. Washington DC: IMF.

Rojas-Suarez, Liliana (1991) "Risk and Capital Flight in Developing Countries," IMF Occasional Working Paper no. 77: Determinants and Systemic Consequences of International Capital Flows.

Roubini, Nouriel and Jeffrey Sachs (1989a) "Government Spending and Budget Deficits in the Industrial Economies," NBER Working Paper no. 2919.

Roubini, Nouriel and Jeffrey Sachs (1989b) "Political and Economic Determinants of Budget Deficits in the Industrial Democracies," European Economic Review, 33,903-938.

Stone, Mark R. (1991) "On the Information Content of LDC Secondary Loan Market Prices," , IMF Working Paper no 91/20.

Thornbecke, Erik (1992) Adjustment and Equity in Indonesia. Development Centre of the Organization of for Economic Co-operation and Development. Paris: OECD.

Varman, Benu (1993) "Capital Flight as a Response to Economic and Political Instability: A Case Study of Argentina," preliminary draft.

Varman, Benu (1989) "Capital Flight - A Critique of Concepts and Measures including a case study of India and the Philippines," HWWA-Institut fur Wirtschaftsforschung, Verlag Weltarchiv, Hamburg, West Germany.

Varman, Benu and Wolfgang Schneider (1989) "Measuring Capital Flight: A Time Varying Regression Analysis, Universitat Kiel Discussion Paper No. 82/89, December.

Zedillo, Ernesto (1987) "Case Study: Mexico," in Capital Flight and Third World Debt, eds. D.R. Lessard and J. Williamson. Washington DC: Institute for International Economics. 

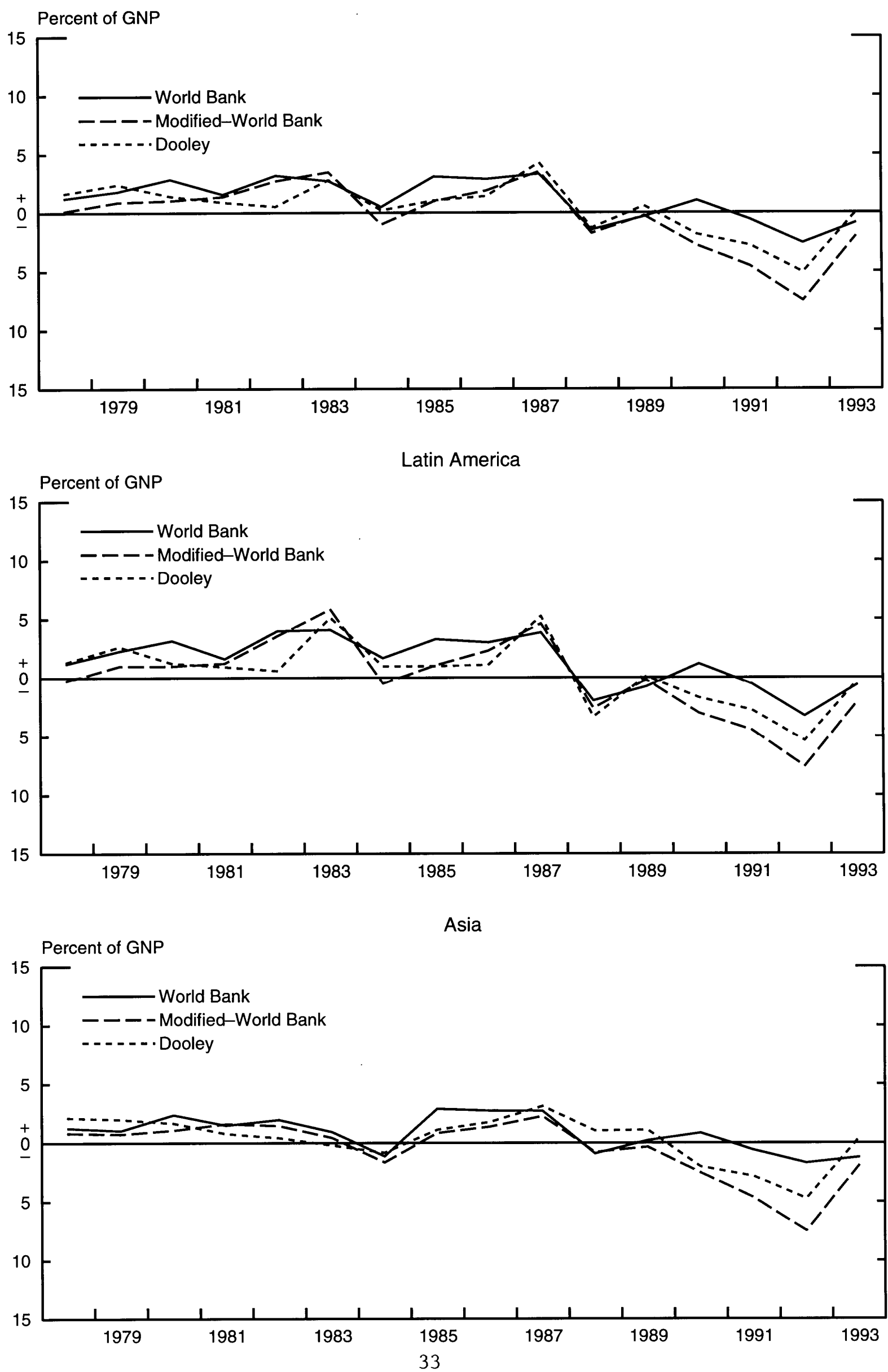


\section{Table 1}

CAPITAL FLIGHT

(Percent of GNP)*

\begin{tabular}{|c|c|c|c|}
\hline \multirow{2}{*}{ Year } & \multicolumn{3}{|c|}{$\underline{\text { Modified }}$} \\
\hline & World Bank & World Bank & Dooley Flow \\
\hline 1978 & 1.21 & 0.14 & 1.62 \\
\hline 1979 & 1.80 & 0.88 & 2.39 \\
\hline 1980 & 2.85 & 1.00 & 1.39 \\
\hline 1981 & 1.56 & 1.36 & 0.87 \\
\hline 1982 & 3.18 & 2.72 & 0.51 \\
\hline 1983 & 2.70 & 3.48 & 2.80 \\
\hline 1984 & 0.46 & -1.00 & 0.19 \\
\hline 1985 & 3.10 & 0.94 & 1.01 \\
\hline 1986 & 2.87 & 1.87 & 1.38 \\
\hline 1987 & 3.31 & 3.52 & 4.26 \\
\hline 1988 & -1.48 & -1.77 & -1.31 \\
\hline 1989 & -0.34 & -0.27 & 0.55 \\
\hline 1990 & 1.01 & -2.83 & -1.86 \\
\hline 1991 & -0.58 & -4.57 & -2.82 \\
\hline 1992 & -2.60 & -7.54 & -5.12 \\
\hline 1993 & -0.88 & -2.06 & -0.04 \\
\hline
\end{tabular}

* GNP-Weighted Average of 17 Developing Countries 

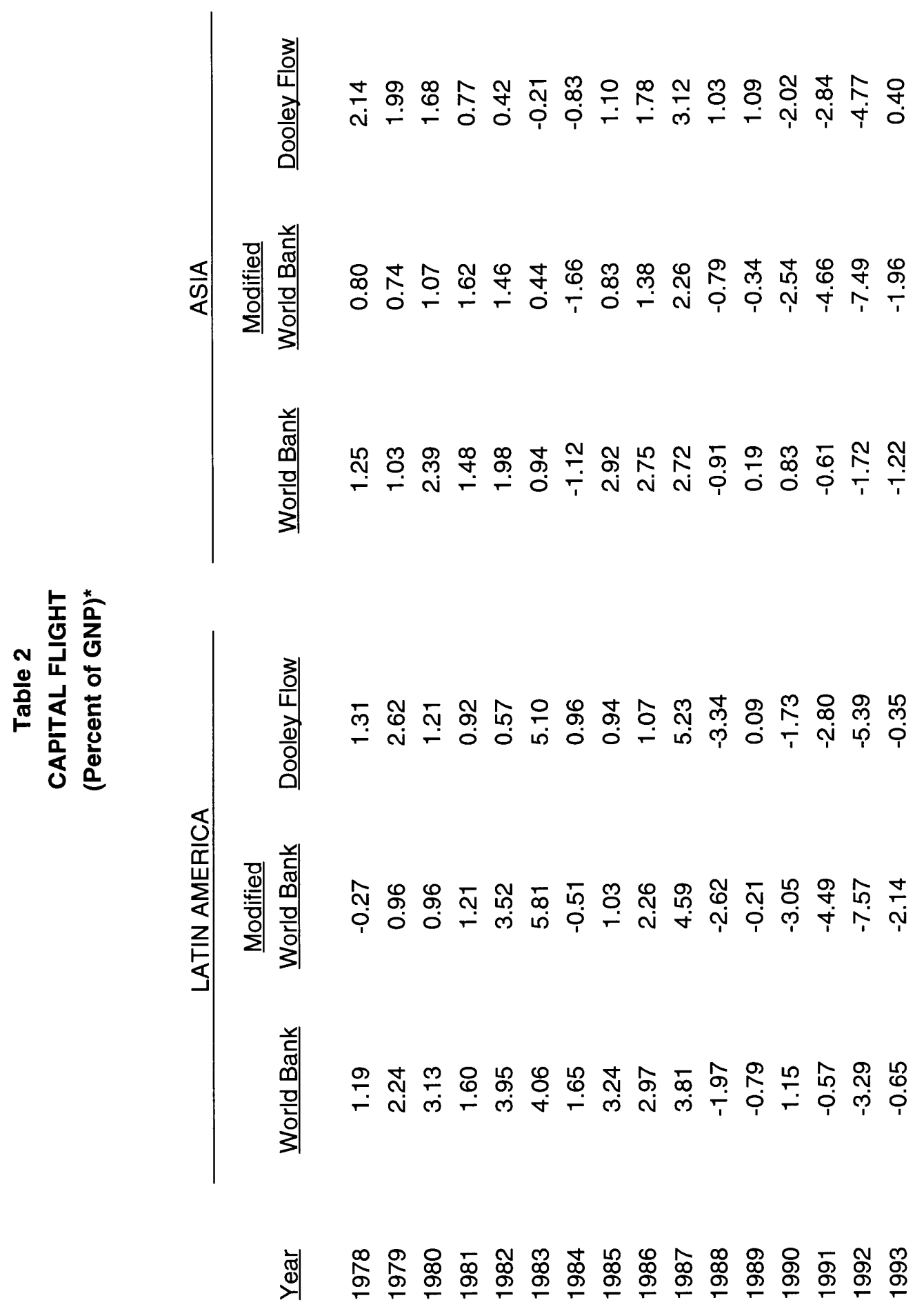
๓

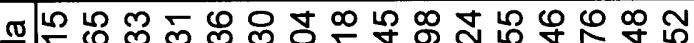

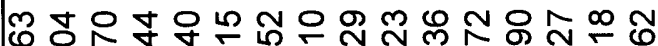
䒛 Nָ

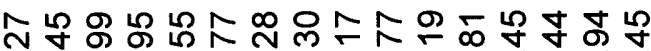
ग्र

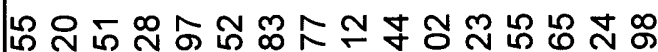
落

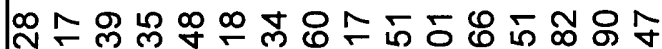

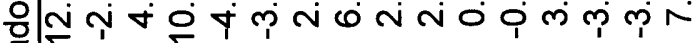

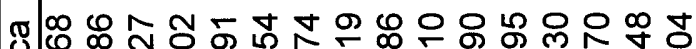

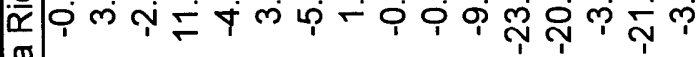

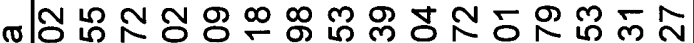
制

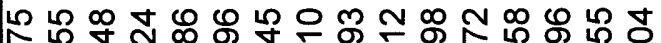
ه

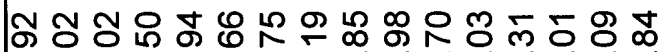

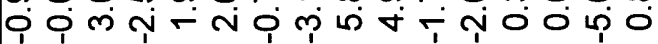

엉유 疋 N

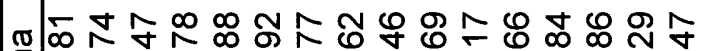
紊

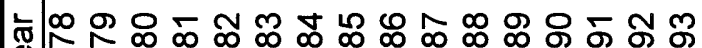

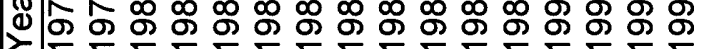

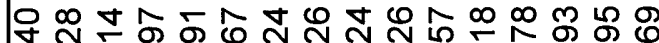

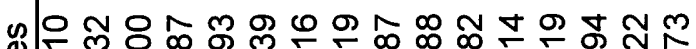

2

돈 m

సิㅇㅇํํㅇำ ه్ర

๙ פ००

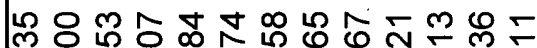
ه

흐

๘ 
Table 4

\section{World Bank Capital Flight Measure} (1978-1993)

\begin{tabular}{lccc} 
& i.i.d. Error-term & \multicolumn{2}{c}{ Country-specific Error-term } \\
\cline { 2 - 4 } & & Fixed-effects & Random-effects \\
Constant & -0.0082 & & 0.1751 \\
& $(0.0315)$ & & $(0.6190)$ \\
& $((-0.2607))$ & & $((0.2828))$ \\
Interest rate & -0.0000 & -0.0000 & -0.0000 \\
differential & $(0.0000)$ & $(0.0000)$ & $(0.0000)$ \\
& $((-0.4978))$ & $((-1.5953))$ & $((-0.3773))$ \\
Black market & 0.0138 & 0.0027 & 0.0146 \\
premium & $(0.0374)$ & $(0.0602)$ & $(0.0365)$ \\
& $((0.3697))$ & $((0.0457))$ & $((0.3985))$ \\
Central goverment & -0.0066 & -0.0073 & -0.0066 \\
surplus as share of GDP & $(0.0033)$ & $(0.0054)$ & $(0.0032)$ \\
& $((-2.0117))^{\mathrm{b}}$ & $((-1.3431))$ & $((-2.0566))^{\mathrm{b}}$ \\
IMF program & -0.0036 & -0.0072 & -0.0033 \\
in effect & $(0.0072)$ & $(0.0093)$ & $(0.0071)$ \\
& $((-0.4972))$ & $((-0.7716))$ & $((-0.4646))$ \\
Capital controls & -0.0092 & -0.0063 & -0.0093 \\
& $(0.0056)$ & $(0.0099)$ & $(0.0055)$ \\
& $((-1.6265))$ & $((-0.6375))$ & $((-1.7015))^{\mathrm{b}}$ \\
Log-Likelihood & & & \\
Breusch-Pagan test & 409.21 & 437.06 & 406.68 \\
Wu-Hausman test & $7296.25^{\mathrm{a}}$ & & \\
& 8.26 & &
\end{tabular}

*Instruments for the black market premium and government surplus are fitted values from reduced form OLS regressions of these variables on a constant, the interest rate differential IMF, capital controls, domestic inflation, foreign infational, lagged domestic and foreign interest rates, lagged publically guaranted external debt, grow real GDP, real official exchange rate, change in domestic money supply.

(standard errors); ((t-statistics)); ${ }^{\mathrm{a}}$ significant at the $1 \%$ level, ${ }^{\mathrm{b}}$ significant at the $5 \%$ level. 
Table 5

\section{Modified-World Bank Capital Flight Measure (1978-1993)*}

\begin{tabular}{lccc} 
& i.i.d. Error-term & \multicolumn{2}{c}{ Country-specific Error-term } \\
\cline { 2 - 4 } & & Fixed-effects & Random-effects \\
Constant & -0.0125 & & -0.0839 \\
& $(0.0587)$ & & $(0.4962)$ \\
& $((-0.2122))$ & & $((-0.1691))$ \\
Interest rate & -0.0000 & -0.0000 & -0.0000 \\
differential & $(0.0000)$ & $(0.0000)$ & $(0.0000)$ \\
& $((-0.0146))$ & $((-0.8507))$ & $((-0.1660))$ \\
Black market & -0.0486 & -0.0669 & -0.0508 \\
premium & $(0.0709)$ & $(0.0823)$ & $(0.0723)$ \\
& $((-0.6848))$ & $((-0.8129))$ & $((-0.7032))$ \\
Central goverment & -0.0180 & -0.0203 & -0.0183 \\
surplus as share of GDP & $(0.0064)$ & $(0.0076)$ & $(0.0066)$ \\
& $(-2.8022))^{\mathrm{a}}$ & $((-2.6563))^{\mathrm{a}}$ & $((-2.7872))^{\mathrm{a}}$ \\
& & & \\
IMF program & -0.0095 & -0.0148 & -0.0102 \\
in effect & $(0.0124)$ & $(0.0152)$ & $(0.0127)$ \\
& $((-0.7632))$ & $((-0.9772))$ & $((-0.8021))$ \\
Capital controls & 0.0064 & 0.0032 & 0.0063 \\
& $(0.0101)$ & $(0.0145)$ & $(0.0105)$ \\
& $((0.6350))$ & $((0.2180))$ & $((0.5992))$ \\
Log-Likelihood & 267.38 & 291.02 & 271.94 \\
Breusch-Pagan test & $14406.82^{\mathrm{a}}$ & & \\
Wu-Hausman test & $15.96^{\mathrm{a}}$ & & \\
& & &
\end{tabular}

*Sample excludes India due to unavailable data.

**Instruments for the black market premium and government surplus are fitted values from reduced form OLS regressions of these variables on a constant, the interest rate differential, IMF, capital controls, domestic inflation, foreign inflation, lagged domestic and foreign interest rates, lagged publically guaranted external debt, grow real GDP, real official exchange rate, change in domestic money supply.

(standard errors); ((t-statistics) $) ;{ }^{\text {a }}$ significant at the $1 \%$ level, ${ }^{\mathrm{b}}$ significant at the $5 \%$ level. 
Table 6

\section{Dooley Flow Capital Flight Measure \\ $(1978-1992)^{*}$}

\begin{tabular}{|c|c|c|c|}
\hline \multirow{2}{*}{\multicolumn{2}{|c|}{ i.i.d. Error-term }} & \multicolumn{2}{|c|}{ Country-specific Error-term } \\
\hline & & Fixed-effects & Random-effects \\
\hline Constant & $\begin{array}{c}0.0109 \\
(0.0493) \\
((0.2200)\end{array}$ & & $\begin{array}{c}0.0118 \\
(0.0989) \\
((0.1192))\end{array}$ \\
\hline $\begin{array}{l}\text { Interest rate } \\
\text { differential }\end{array}$ & $\begin{array}{c}-0.0000 \\
(0.0000) \\
((-0.4429))\end{array}$ & $\begin{array}{c}-0.0000 \\
(0.0000) \\
((-0.8235))\end{array}$ & $\begin{array}{c}0.0000 \\
(0.0000) \\
((0.4662))\end{array}$ \\
\hline $\begin{array}{l}\text { Black market } \\
\text { premium }\end{array}$ & $\begin{array}{c}-0.0436 \\
(0.0598) \\
((-0.7295))\end{array}$ & $\begin{array}{c}-0.0945 \\
(0.0860) \\
((-1.0981))\end{array}$ & $\begin{array}{c}-0.0187 \\
(0.0466) \\
((-0.4018))\end{array}$ \\
\hline $\begin{array}{l}\text { Central goverment } \\
\text { surplus as share of GDP }\end{array}$ & $\begin{array}{c}-0.0127 \\
(0.0055) \\
((-2.3102))^{\mathrm{b}}\end{array}$ & $\begin{array}{c}-0.0174 \\
(0.0082)) \\
((-2.1053))^{\mathrm{b}}\end{array}$ & $\begin{array}{c}-0.0100 \\
(0.0041) \\
((-2.4215))^{\mathrm{a}}\end{array}$ \\
\hline $\begin{array}{l}\text { IMF program } \\
\text { in effect }\end{array}$ & $\begin{array}{c}-0.0082 \\
(0.0116) \\
((-0.7092))\end{array}$ & $\begin{array}{l}-0.0146 \\
(0.0162) \\
((-.08962))\end{array}$ & $\begin{array}{c}-0.0063 \\
(0.0095) \\
((-0.6635))\end{array}$ \\
\hline Capital controls & $\begin{array}{c}0.0036 \\
(0.0094) \\
((0.3874))\end{array}$ & $\begin{array}{c}0.0133 \\
(0.0171) \\
((0.7787))\end{array}$ & $\begin{array}{c}-0.0001 \\
(0.0067) \\
((-0.0122))\end{array}$ \\
\hline Log-Likelihood & 270.10 & 265.25 & 260.14 \\
\hline $\begin{array}{l}\text { Breusch-Pagan test } \\
\text { Wu-Hausman test }\end{array}$ & $\begin{array}{r}2945.32^{\mathrm{a}} \\
12.71^{\mathrm{b}}\end{array}$ & & \\
\hline
\end{tabular}

*Sample ends in 1992 and excludes India due to unavailable data.

**Instruments for the black market premium and government surplus are fitted values from reduced form OLS regressions of these variables on a constant, the interest rate differential, IMF, capital controls, domestic inflation, foreign inflation, lagged domestic and foreign interest rates, lagged publically guaranted external debt, grow real GDP, real official exchange rate, change in domestic money supply.

(standard errors); ((t-statistics)); ${ }^{\mathrm{a}}$ significant at the $1 \%$ level, ${ }^{\mathrm{b}}$ significant at the $5 \%$ level. 
Table 7

\section{World Bank Capital Flight Measure $(1986-1993)^{*}$}

\begin{tabular}{|c|c|c|c|}
\hline \multirow{2}{*}{\multicolumn{2}{|c|}{ i.i.d. Error-term }} & \multicolumn{2}{|c|}{ Country-specific Error-term } \\
\hline & & Fixed-effects & Random-effects \\
\hline Constant & $\begin{array}{c}-0.0674 \\
(0.0513) \\
((-1.3142))\end{array}$ & & $\begin{array}{c}-0.1771 \\
(0.1529) \\
((-1.1581))\end{array}$ \\
\hline $\begin{array}{l}\text { Interest rate } \\
\text { differential }\end{array}$ & $\begin{array}{c}-0.0000 \\
(0.0000) \\
((-0.0421))\end{array}$ & $\begin{array}{c}-0.0000 \\
(0.0000) \\
((-0.3023))\end{array}$ & $\begin{array}{c}-0.0000 \\
(0.0000) \\
((-0.3285))\end{array}$ \\
\hline $\begin{array}{l}\text { Black market } \\
\text { premium }\end{array}$ & $\begin{array}{c}0.0439 \\
(0.0469) \\
((0.9362))\end{array}$ & $\begin{array}{c}0.0016 \\
(0.0718) \\
((0.0225))\end{array}$ & $\begin{array}{c}0.0355 \\
(0.0475) \\
((0.7476))\end{array}$ \\
\hline $\begin{array}{l}\text { Central goverment } \\
\text { surplus as share of GDP }\end{array}$ & $\begin{array}{c}-0.0062 \\
(0.0041) \\
((-1.5222))\end{array}$ & $\begin{array}{c}-0.0104 \\
(0.0085) \\
((-1.2272))\end{array}$ & $\begin{array}{c}-0.0069 \\
(0.0048) \\
((-1.4575))\end{array}$ \\
\hline $\begin{array}{l}\text { IMF program } \\
\text { in effect }\end{array}$ & $\begin{array}{c}0.0020 \\
(0.0162) \\
((0.1221))\end{array}$ & $\begin{array}{c}-0.0159 \\
(0.0213) \\
((-0.7457))\end{array}$ & $\begin{array}{c}-0.0027 \\
(0.0164) \\
((-0.1669))\end{array}$ \\
\hline Capital controls & $\begin{array}{c}-0.0031 \\
(0.0116) \\
((-0.2691))\end{array}$ & $\begin{array}{c}0.0013 \\
(0.0180) \\
((0.0715))\end{array}$ & $\begin{array}{c}-0.0025 \\
(0.0127) \\
((-0.1975))\end{array}$ \\
\hline $\begin{array}{l}\text { Secondary prices } \\
\text { of bank debt }\end{array}$ & $\begin{array}{c}-0.0004 \\
(0.0021) \\
((-0.1998))\end{array}$ & $\begin{array}{c}-0.0013 \\
(0.0021) \\
((-0.6186))\end{array}$ & $\begin{array}{c}-0.0006 \\
(0.0020) \\
((-0.3228))\end{array}$ \\
\hline Log-Likelihood & 115.71 & 134.24 & 122.54 \\
\hline $\begin{array}{l}\text { Breusch-Pagan test } \\
\text { Wu-Hausman test }\end{array}$ & $\begin{array}{c}525.83^{\mathrm{a}} \\
1.79\end{array}$ & & \\
\hline
\end{tabular}

*Sample includes the eleven countries for which secondary prices of bank debt were available: Argentina, Bolivia, Brazil, Colombia, Chile, Ecuador, Mexico, Peru, the Philippines, Uruguay, Venezuela.

**Instruments for the black market premium and government surplus are fitted values from reduced form OLS regressions of these variables on a constant, the interest rate differential, IMF, capital controls, domestic inflation, foreign inflation, lagged domestic and foreign interest rates, lagged publically guaranted external debt, grow real GDP, real official exchange rate, change in domestic money supply.

*** Secondary market prices were regressed on the U.S. dollar-denominated LIBOR and the IMF index of commodity prices for developing countries using OLS; the coefficient of variation of monthly OLS residuals serve as regressors.

(standard errors); ((t-statistics) $) ;{ }^{\mathrm{a}}$ significant at the $1 \%$ level, ${ }^{\mathrm{b}}$ significant at the $5 \%$ level. 
Table 8

\section{Modified-World Bank Capital Flight Measure (1986-1993)*}

\begin{tabular}{|c|c|c|c|}
\hline \multirow{2}{*}{\multicolumn{2}{|c|}{ i.i.d. Error-term }} & \multicolumn{2}{|c|}{ Country-specific Error-term } \\
\hline & & Fixed-effects & Random-effects \\
\hline Constant & $\begin{array}{c}-0.1642 \\
(0.0666) \\
((-2.4657))^{\mathrm{b}}\end{array}$ & & $\begin{array}{c}1.1013 \\
(0.4002) \\
((2.7520))^{\mathrm{a}}\end{array}$ \\
\hline $\begin{array}{l}\text { Interest rate } \\
\text { differential }\end{array}$ & $\begin{array}{c}0.0000 \\
(0.0000) \\
((0.4515))\end{array}$ & $\begin{array}{c}0.0000 \\
(0.0000) \\
((0.5194))\end{array}$ & $\begin{array}{c}0.0000 \\
(0.0000) \\
((0.6779))\end{array}$ \\
\hline $\begin{array}{l}\text { Black market } \\
\text { premium }\end{array}$ & $\begin{array}{c}0.0580 \\
(0.0609) \\
((0.9525))\end{array}$ & $\begin{array}{c}-0.0961 \\
(0.1368) \\
((-0.7026))\end{array}$ & $\begin{array}{c}0.0753 \\
(0.0613) \\
((1.2299))\end{array}$ \\
\hline $\begin{array}{l}\text { Central goverment } \\
\text { surplus as share of GDP }\end{array}$ & $\begin{array}{c}-0.0167 \\
(0.0053) \\
((-3.1388))^{\mathrm{a}}\end{array}$ & $\begin{array}{c}-0.0346 \\
(0.0161) \\
((-2.1479))^{\mathrm{b}}\end{array}$ & $\begin{array}{c}-0.0150 \\
(0.0047) \\
((-3.1720))^{\mathrm{a}}\end{array}$ \\
\hline $\begin{array}{l}\text { IMF program } \\
\text { in effect }\end{array}$ & $\begin{array}{c}-0.0114 \\
(0.0210) \\
((-0.5409))\end{array}$ & $\begin{array}{c}-0.0683 \\
(0.0407) \\
((-1.6804))\end{array}$ & $\begin{array}{c}-0.0007 \\
(0.0207) \\
((-0.0361))\end{array}$ \\
\hline Capital controls & $\begin{array}{c}0.0115 \\
(0.0151) \\
((0.7656))\end{array}$ & $\begin{array}{c}0.0129 \\
(0.0343) \\
((0.3778))\end{array}$ & $\begin{array}{c}0.0132 \\
(0.0139) \\
((0.9481))\end{array}$ \\
\hline $\begin{array}{l}\text { Secondary price } \\
\text { of bank debt } \\
\text { residuals }\end{array}$ & $\begin{array}{c}-0.0021 \\
(0.0027) \\
((-0.7816))\end{array}$ & $\begin{array}{c}-0.0049 \\
(0.0040) \\
((-1.2331))\end{array}$ & $\begin{array}{c}-0.0017 \\
(0.0028) \\
((-0.6037))\end{array}$ \\
\hline Log-Likelihood & 92.66 & 77.52 & 88.50 \\
\hline $\begin{array}{l}\text { Breusch-Pagan test } \\
\text { Wu-Hausman test }\end{array}$ & $293.16^{\mathrm{a}}$ & & \\
\hline
\end{tabular}

*Sample includes the eleven countries for which secondary prices of bank debt were available: Argentina, Bolivia, Brazil, Colombia, Chile, Ecuador, Mexico, Peru, the Philippines, Uruguay, Venezuela.

**Instruments for the black market premium and government surplus are fitted values from reduced form OLS regressions of these variables on a constant, the interest rate differential, IMF, capital controls, domestic inflation, foreign inflation, lagged domestic and foreign interest rates, lagged publically guaranted external debt, grow real GDP, real official exchange rate, change in domestic money supply.

*** Secondary market prices were regressed on the U.S. dollar-denominated LIBOR and the IMF index of commodity prices for developing countries using OLS; the coefficient of variation of monthly OLS residuals serve as regressors.

(standard errors); ((t-statistics) $) ;{ }^{\mathrm{a}}$ significant at the $1 \%$ level, ${ }^{\mathrm{b}}$ significant at the $5 \%$ level. 
Table 9

\section{Dooley Flow Capital Flight Measure \\ $(1986-1992)^{*}$}

i.i.d. Error-term

\begin{tabular}{|c|c|c|c|}
\hline & i.i.d. Error-term & Country-sp & c Error-term \\
\hline & & Fixed-effects & Random-effects \\
\hline Constant & $\begin{array}{c}-0.1414 \\
(0.0670) \\
((-2.1098))^{b}\end{array}$ & & $\begin{array}{c}0.4707 \\
(0.2263) \\
((2.0801))^{\mathrm{b}}\end{array}$ \\
\hline $\begin{array}{l}\text { Interest rate } \\
\text { differential }\end{array}$ & $\begin{array}{c}0.0000 \\
(0.0000) \\
((0.1310))\end{array}$ & $\begin{array}{c}0.0000 \\
(0.0000) \\
((0.9577))\end{array}$ & $\begin{array}{c}0.0000 \\
(0.0000) \\
((1.2117))\end{array}$ \\
\hline $\begin{array}{l}\text { Black market } \\
\text { premium }\end{array}$ & $\begin{array}{c}0.0389 \\
(0.0571) \\
((0.6818))\end{array}$ & $\begin{array}{c}-0.2440 \\
(0.1828) \\
((-1.3345))\end{array}$ & $\begin{array}{c}0.1613 \\
(0.1092) \\
((1.4778))\end{array}$ \\
\hline $\begin{array}{l}\text { Central goverment } \\
\text { surplus as share of GDP }\end{array}$ & $\begin{array}{c}-0.0134 \\
(0.0051) \\
((-2.6311))^{\mathrm{a}}\end{array}$ & $\begin{array}{c}-0.0364 \\
(0.0206) \\
((-1.7670))^{\mathrm{b}}\end{array}$ & $\begin{array}{c}-0.0086 \\
(0.0044) \\
((-1.9512))^{\mathrm{b}}\end{array}$ \\
\hline $\begin{array}{l}\text { IMF program } \\
\text { in effect }\end{array}$ & $\begin{array}{c}0.0004 \\
(0.0236) \\
((0.0155))\end{array}$ & $\begin{array}{c}-0.0791 \\
(0.0626) \\
((-1.2636))\end{array}$ & $\begin{array}{c}0.0378 \\
(0.0301) \\
((1.2553))\end{array}$ \\
\hline Capital controls & $\begin{array}{c}0.0165 \\
(0.0184) \\
((0.8962))\end{array}$ & $\begin{array}{c}0.0876 \\
(0.0659) \\
((1.3294))\end{array}$ & $\begin{array}{c}0.0037 \\
(0.0172) \\
((0.2134))\end{array}$ \\
\hline $\begin{array}{l}\text { Secondary price } \\
\text { of bank debt } \\
\text { residuals }\end{array}$ & $\begin{array}{c}-0.0021 \\
(0.0027) \\
((-0.7649))\end{array}$ & $\begin{array}{c}-0.0072 \\
(0.0054) \\
((-1.3244))\end{array}$ & $\begin{array}{c}0.0028 \\
(0.0047) \\
((0.6010))\end{array}$ \\
\hline Log-Likelihood & 80.91 & 49.17 & 37.38 \\
\hline $\begin{array}{l}\text { Breusch-Pagan test } \\
\text { Wu-Hausman test }\end{array}$ & $106.06^{\mathrm{a}}$ & & \\
\hline
\end{tabular}

Country-specific Error-term

\begin{tabular}{|c|c|c|c|}
\hline & i.i.d. Error-term & Country-sp & ic Error-term \\
\hline & & Fixed-effects & Random-effects \\
\hline Constant & $\begin{array}{c}-0.1414 \\
(0.0670) \\
((-2.1098))^{\mathrm{b}}\end{array}$ & & $\begin{array}{c}0.4707 \\
(0.2263) \\
((2.0801))^{\mathrm{b}}\end{array}$ \\
\hline $\begin{array}{l}\text { Interest rate } \\
\text { differential }\end{array}$ & $\begin{array}{c}0.0000 \\
(0.0000) \\
((0.1310))\end{array}$ & $\begin{array}{c}0.0000 \\
(0.0000) \\
((0.9577))\end{array}$ & $\begin{array}{c}0.0000 \\
(0.0000) \\
((1.2117))\end{array}$ \\
\hline $\begin{array}{l}\text { Black market } \\
\text { premium }\end{array}$ & $\begin{array}{c}0.0389 \\
(0.0571) \\
((0.6818))\end{array}$ & $\begin{array}{c}-0.2440 \\
(0.1828) \\
((-1.3345))\end{array}$ & $\begin{array}{c}0.1613 \\
(0.1092) \\
((1.4778))\end{array}$ \\
\hline $\begin{array}{l}\text { Central goverment } \\
\text { surplus as share of GDP }\end{array}$ & $\begin{array}{c}-0.0134 \\
(0.0051) \\
((-2.6311))^{\mathrm{a}}\end{array}$ & $\begin{array}{c}-0.0364 \\
(0.0206) \\
((-1.7670))^{\mathrm{b}}\end{array}$ & $\begin{array}{c}-0.0086 \\
(0.0044) \\
((-1.9512))^{\mathrm{b}}\end{array}$ \\
\hline $\begin{array}{l}\text { IMF program } \\
\text { in effect }\end{array}$ & $\begin{array}{c}0.0004 \\
(0.0236) \\
((0.0155))\end{array}$ & $\begin{array}{c}-0.0791 \\
(0.0626) \\
((-1.2636))\end{array}$ & $\begin{array}{c}0.0378 \\
(0.0301) \\
((1.2553))\end{array}$ \\
\hline Capital controls & $\begin{array}{c}0.0165 \\
(0.0184) \\
((0.8962))\end{array}$ & $\begin{array}{c}0.0876 \\
(0.0659) \\
((1.3294))\end{array}$ & $\begin{array}{c}0.0037 \\
(0.0172) \\
((0.2134))\end{array}$ \\
\hline $\begin{array}{l}\text { Secondary price } \\
\text { of bank debt } \\
\text { residuals }\end{array}$ & $\begin{array}{c}-0.0021 \\
(0.0027) \\
((-0.7649))\end{array}$ & $\begin{array}{c}-0.0072 \\
(0.0054) \\
((-1.3244))\end{array}$ & $\begin{array}{c}0.0028 \\
(0.0047) \\
((0.6010))\end{array}$ \\
\hline Log-Likelihood & 80.91 & 49.17 & 37.38 \\
\hline $\begin{array}{l}\text { Breusch-Pagan test } \\
\text { Wu-Hausman test }\end{array}$ & $106.06^{\mathrm{a}}$ & & \\
\hline
\end{tabular}

*Sample ends in 1992 due to data availability and includes the nine countries for which both secondary prices of bank debt and detailed BOP data were available: Argentina, Brazil, Chile, Ecuador, Mexico, Peru, the Philippines, Uruguay, Venezuela.

**Instruments for the black market premium and government surplus are fitted values from reduced form OLS regressions of these variables on a constant, the interest rate differential, IMF, capital controls, domestic inflation, foreign inflation, lagged domestic and foreign interest rates, lagged publically guaranted external debt, grow real GDP, real official exchange rate, change in domestic money supply.

*** Secondary market prices were regressed on the U.S. dollar-denominated LIBOR and the IMF index of commodity prices for developing countries using OLS; the coefficient of variation of monthly OLS residuals serve as regressors.

(standard errors); ((t-statistics)); ${ }^{\mathrm{a}}$ significant at the $1 \%$ level, ${ }^{\mathrm{b}}$ significant at the $5 \%$ level. 
Table 10

\section{World Bank Capital Flight Measure (1978-1993)*}

Fixed-effects System of Simultaneous Equations

Interest rate

differential

Black market

premium

Central goverment surplus as share of GDP

IMF program

in effect

Capital controls

Secondary prices

of bank debt

Log-Likelihood
$-0.0000$
(0.0000)
$((-1.1860))$
(0.0000)
$((-1.0785))$

$-0.0593$

(0.0461)

0.0763

$((-1.2866))$

(0.0649)

((1.1752))

$-0.0119$

$(0.0040$

$-0.0001$

$(-3.0172))^{\mathrm{a}}$

(0.0077)

$((-0.0179))$

$-0.0129$

(0.0092)

0.0025

$((-1.3997))$

$(0.0217)$

((0.1147))

0.0021
$(0.0094)$
$((0.2294))$

$-0.0035$

(0.0192)

$((-0.1836))$

0.0002

$(0.0022)$

$((0.0835))$

408.01

123.76

* When we include secondary prices as a regressor, the sample only includes data from 1986 through 1993 for those countries where secondary prices of bank debt were available: Argentina, Bolivia, Brazil, Colombia, Chile, Ecuador, Mexico, Peru, the Philippines, Uruguay, Venezuela.

** Instruments for the black market premium and government surplus are fitted values from reduced form Fixed-effect regressions of these variables on a the interest rate differential, IMF, capital controls, domestic inflation, foreign inflation, lagged domestic and foreign interest rates, lagged publically guaranted external debt, grow real GDP, real official exchange rate, change in domestic money supply.

*** Secondary market prices were regressed on the U.S. dollar-denominated LIBOR and the IMF index of commodity prices for developing countries using OLS; the coefficient of variation of monthly OLS residuals serve as regressors.

(standard errors); ((t-statistics)); ${ }^{\text {a }}$ significant at the $1 \%$ level, ${ }^{\mathrm{b}}$ significant at the $5 \%$ level. 
Table 11

\section{Modified-World Bank Capital Flight Measure (1978-1993)*}

Fixed-effects System of Simultaneous Equations

$\begin{array}{lcc}\begin{array}{lcc}\text { Interest rate } \\ \text { differential }\end{array} & -0.0000 & -0.0000 \\ & ((-0.0000) & (0.0000) \\ & & ((-0.4459)) \\ \text { Black market } & -0.1142 & \\ \text { premium } & (0.0693) & 0.0484 \\ & ((-1.6480)) & (0.0761) \\ & -0.0237 & ((0.6360)) \\ \text { Central goverment } & (0.0059) & -0.0155 \\ \text { surplus as share of GDP } & (-4.0091)^{\mathrm{a}} & ((-1.7206))^{\mathrm{b}} \\ & -0.0198 & -0.0338 \\ & (0.0153) & (0.0254) \\ \text { IMF program } & ((-1.2961)) & ((-1.3274)) \\ \text { in effect } & & 0.0023 \\ & 0.0097 & (0.0225) \\ \text { Capital controls } & (0.0145) & ((0.1041)) \\ & ((0.6701)) & -0.0022 \\ & & (0.0026) \\ \text { Secondary prices } & & ((-0.8327)) \\ \text { of bank debt } & & 109.80\end{array}$

* When we include secondary prices as a regressor, the sample only includes data from 1986 through 1993 for those countries where secondary prices of bank debt were available: Argentina, Bolivia, Brazil, Colombia, Chile, Ecuador, Mexico, Peru, the Philippines, Uruguay, Venezuela.

** Instruments for the black market premium and government surplus are fitted values from reduced form Fixed-effect regressions of these variables on a the interest rate differential, IMF, capital controls, domestic inflation, foreign inflation, lagged domestic and foreign interest rates, lagged publically guaranted external debt, grow real GDP, real official exchange rate, change in domestic money supply.

*** Secondary market prices were regressed on the U.S. dollar-denominated LIBOR and the IMF index of commodity prices for developing countries using OLS; the coefficient of variation of monthly OLS residuals serve as regressors.

(standard errors); ((t-statistics)); ${ }^{a}$ significant at the $1 \%$ level, ${ }^{\mathrm{b}}$ significant at the $5 \%$ level. 


\section{Table 12}

\section{Dooley Flow Capital Flight Measure \\ $(1978-1992)^{*}$}

\section{Fixed-effects System of Simultaneous Equations}

$\begin{array}{lcc}\begin{array}{lcc}\text { Interest rate } \\ \text { differential }\end{array} & -0.0000 & 0.0000 \\ & ((-0.0000) & (0.0000) \\ & & ((0.5826)) \\ \text { Black market } & -0.1433 & \\ \text { premium } & (0.0758) & -0.0953 \\ & ((-1.8899))^{\mathrm{b}} & ((0.0984) \\ & -0.0211 & ((-0.9682)) \\ \text { Central goverment } & (0.0067) & -0.0202 \\ \text { surplus as share of GDP } & ((-3.1375))^{\mathrm{a}} & (0.0113) \\ & -0.0200 & ((-1.7911))^{\mathrm{b}} \\ & (0.0169) & -0.0408 \\ \text { IMF program } & ((-1.1869)) & (0.0362) \\ \text { in effect } & & ((-1.1264)) \\ & 0.0211 & 0.0646 \\ \text { Capital controls } & (0.0174) & (0.0394) \\ & ((1.2088)) & ((1.6398)) \\ & & -0.0045 \\ \text { Secondary prices } & & (0.0032) \\ \text { of bank debt } & ((-1.4054)) \\ & & 85.66\end{array}$

* When we include secondary prices as a regressor, the sample only includes data from 1986 through 1992 for those countries where secondary prices of bank debt were available: Argentina, Bolivia, Brazil, Colombia, Chile, Ecuador, Mexico, Peru, the Philippines, Uruguay, Venezuela.

** Instruments for the black market premium and government surplus are fitted values from reduced form Fixed-effect regressions of these variables on a the interest rate differential, IMF, capital controls, domestic inflation, foreign inflation, lagged domestic and foreign interest rates, lagged publically guaranted external debt, grow real GDP, real official exchange rate, change in domestic money supply.

*** Secondary market prices were regressed on the U.S. dollar-denominated LIBOR and the IMF index of commodity prices for developing countries using OLS; the coefficient of variation of monthly OLS residuals serve as regressors.

(standard errors); ((t-statistics) $) ;{ }^{\mathrm{a}}$ significant at the $1 \%$ level, ${ }^{\mathrm{b}}$ significant at the $5 \%$ level. 
Table XX

\section{World Bank Capital Flight Measure} $(1978-1993)^{*}$

\begin{tabular}{|c|c|c|c|}
\hline \multirow{2}{*}{\multicolumn{2}{|c|}{ i.i.d. Error-term }} & \multicolumn{2}{|c|}{ Country-specific Error-term } \\
\hline & & Fixed-effects & Random-effects \\
\hline Constant & $\begin{array}{c}0.0352 \\
(0.0412) \\
((0.8552))\end{array}$ & & $\begin{array}{c}0.0933 \\
(0.0942) \\
((0.9905))\end{array}$ \\
\hline $\begin{array}{l}\text { Interest rate } \\
\text { differential }\end{array}$ & $\begin{array}{c}-0.0000 \\
(0.0000) \\
((-0.1587))\end{array}$ & $\begin{array}{c}-0.0000 \\
(0.0000) \\
((-1.1631))\end{array}$ & $\begin{array}{c}-0.0000 \\
(0.0000) \\
((-0.6997))\end{array}$ \\
\hline $\begin{array}{l}\text { Black market } \\
\text { premium }\end{array}$ & $\begin{array}{c}-0.0394 \\
(0.0487) \\
((-0.0895))\end{array}$ & $\begin{array}{c}-0.0577 \\
(0.0447) \\
((-1.2893))\end{array}$ & $\begin{array}{c}-0.0443 \\
(0.0467) \\
((-0.9480))\end{array}$ \\
\hline $\begin{array}{l}\text { Central goverment } \\
\text { surplus as share of GDP }\end{array}$ & $\begin{array}{c}-0.0112 \\
(0.0042) \\
((-2.6386))^{\mathrm{a}}\end{array}$ & $\begin{array}{c}-0.0117 \\
(0.0038) \\
((-3.0743))^{\mathrm{a}}\end{array}$ & $\begin{array}{c}-0.0112 \\
(0.0040) \\
((-2.7889))^{\mathrm{a}}\end{array}$ \\
\hline $\begin{array}{l}\text { IMF program } \\
\text { in effect }\end{array}$ & $\begin{array}{c}-0.0086 \\
(0.0088) \\
((-0.9815))\end{array}$ & $\begin{array}{c}-0.0139 \\
(0.0099) \\
((-1.4100))\end{array}$ & $\begin{array}{c}-0.0106 \\
(0.0091) \\
((-1.1633))\end{array}$ \\
\hline Capital controls & $\begin{array}{c}-0.0027 \\
(0.0070) \\
((-0.3820))\end{array}$ & $\begin{array}{c}0.0021 \\
(0.0094) \\
((0.2228))\end{array}$ & $\begin{array}{c}-0.0015 \\
(0.0075) \\
((-0.2035))\end{array}$ \\
\hline Log-Likelihood & 354.12 & 378.57 & 367.81 \\
\hline $\begin{array}{l}\text { Breusch-Pagan test } \\
\text { Wu-Hausman test }\end{array}$ & $\begin{array}{c}12089.07^{\mathrm{a}} \\
1.51\end{array}$ & & \\
\hline
\end{tabular}

*Sample excludes India to compare with Modified-World Bank Capital Flight results.

**Instruments for the black market premium and government surplus are fitted values from reduced form OLS regressions of these variables on a constant, the interest rate differential IMF, capital controls, domestic inflation, foreign infational, lagged domestic and foreign interest rates, lagged publically guaranted external debt, grow real GDP, real official exchange rate, change in domestic money supply.

(standard errors); ((t-statistics)); ${ }^{a}$ significant at the $1 \%$ level, ${ }^{\mathrm{b}}$ significant at the $5 \%$ level. 